\title{
Policy Implementation and Determinant of Access to Education for Disable Learners in Siaya and Kisumu Counties- Kenya: A Phenomenological Study
}

\author{
Fredrick Ochieng Owuor \\ Ph.D. Candidate at the Graduate School of Public Administration \\ National Institute of Development Administration (NIDA) \\ 118 Moo3, Serithai Road, Klong-Chan, Bangkapi, Bangkok 10240, Thailand
}

Received: May 13, 2018 Accepted: June 5, 2018 Online published: June 13, 2018

doi:10.5296/jpag.v8i2.13276 URL: https://doi.org/10.5296/jpag.v8i2.13276

\begin{abstract}
Access to education denotes approaches which policies and institutions offering education ensures student have equal chances to acquire knowledge and skills to the maximum without compromising one's status socially, economically or physically. Well thought policy implementation strategies can assist this, as such the study borrowed heavily from policy implementation theories. Also, the study was based on interpretative epistemic paradigm and focused on policy context and its influence on access to education by engaging experiences of principals, teachers, parents, education officers and learners living with disability in Kenya, The following objectives directed the research; to explore policy context of students living with disability; to analyze factors influencing policy implementation for access to education among student living with disability; and to recommend strategies for improving access to education for learners living with disability. Data was collected in 3 schools within 2 countries. 3 Principals, 2 parents, 2 education officers, 3 disable learners and 18 teachers formed 3 different focus groups. Both convenience and purposive sampling technique were used to identify the respondent. The study adopted individual as unit of analysis, it applied context analysis, daily dairy recording, semi structured interview and focus group interviews to collect the data. The findings from data analysis shows decision making, awareness, cultural beliefs, Curriculum, Environmental Physical Infrastructural facilities, Teachers Role, Stakeholders/ Government Levels of Authority and Parental support as major factors influencing policy implementation for learners living with disability. The study came up with following policy recommendations.; policy on strategy for decision making in a special school be setup, and policy on research on disability befitting curriculum, facilities, and environmental infrastructural need to be considered among others.
\end{abstract}


Keywords: policy implementation, decision making, curriculum, government role, infrastructure, learner living with disability, access to education, stakeholder

\section{Introduction}

According to UNESCO, disability is one of the least visible but most potent factors in educational marginalization. This is even though educational access, and subsequent success in education is the gateway to change in many other areas of life for individuals with disabilities, nothing will change society's attitudes to disability more than educational access. The way educational laws and policies are formulated and implemented determine the success or failure of the school system, and eventually of the children with disabilities learning. This means that these law and policy instruments have to be reviewed regularly and updated with new trends, knowledge and skills so that the government authority can be well asserted in implementation of policy (Bardach, 1977; Berman, 1978; and Bhuyan, Jorgensen, \& Sharma, 2010). In support of this UNESCO, (1990) stated that access to education refers to ways in which policies in academic institutions endeavour to ensure children have equitable opportunities to take full gain of their education. Therefore, access according to the report involves the need for schools to offer additional services, remove any actual or potential barriers that might prevent some students from equitable participation in certain courses or academic programs. The same notion was mentioned in studies by Najjingo, (2009); Lewin, (2009); Glick, (2008); K. Lewin, (2008); Sifuna, (2007); Sifuna, (2005), and report by, UNESCO, (2014) further noted that despite serious attachment on accessing and achieving quality education, 58 million children aged 6 to 11 are still not in school indicating little improvement since 2007. Many other studies by Burke Daugherty, E, (20150; Elward, (2011); Munene, I., and Ruto, (2010); Ramirez - marin, (2009); Shabaya, J. \& Konadu- Agyemang, (2004); and Karen Aldred, (1991).have pointed out factors hindering access to education as race, religion, gender, sexual orientation, disability, perceived intellectual ability, past academic performance, special-education status, English-language ability, and family income. In Kenya much of the information about students living with disability comes from government reports as well as international conventions and reports. In addition limited studies for instance Muthili, (2010); Somerset, (2011); Harnson Ntabo Oonge, (2013); and Mwangi et al., (2014) have highlighted challenges students living with disability in Kenya face, they recognize the reality of disability and the need for government to respond to challenges people living with disability encounter. However: (1) these studies are not conclusive since the context of Kenya is diverse. This diversity implies context specific requirements which are always missed out in policy decision making; (2) these studies do not explore the perspective of the people living with disability. This is because they make generalized inferences from a range of government or non-governmental records rather than actual studies focusing on the lived experiences of students living with disability.

\subsection{The Study Answered the Following Question}

1. What is the policy context of students living with disability in Kenya with respect to Siaya and Kisumu Counties? 
2. What factors influence policy implementation for access to education among student living with disability in Kenya's Siaya and Kisumu counties?

3. Which strategies can you recommend for access to education for learners living with disability in Siaya and Kisumu counties in Kenya?

\subsection{Significance of the Study}

Sustainable Development Goals (SDGs) recognize all forms of discrimination, inequality and poverty as priority agenda for the next fifteen years. More than before, strategies to address these issues require that governance and institutional mechanisms at local, national, regional and international level be more responsive to such needs enlisted in the priority agenda. Disability is therefore an international public good that requires priority attention from government and non-governmental actors. This is because; $10 \%$ of the world's population are disabled. Analysis of Kenya's education policy indicates a universal application of policy without focus on context specific challenges that are unique to places, group, or sector of society. Often when this is done, marginalized groups or places benefit less from policy, or are largely left out of policy process, in the end this leads to increase in inequalities.

By focusing on three special schools and the context within which challenges students living with disability live and study; this study brought to light experiences from which insights can be drawn to develop responsive need-based policies that can be applied to or inform similar policy situations elsewhere. This study sought to add the voice of disable students, their parents, teachers and education officers to the discussion on reforming the education in Kenya in response to the new constitution that binds Kenya to international obligations (RoK, 2010). This is a perspective that had not been captured in the previous studies.

Equally the study gave insights of possible reasons why these learners are unable to access educations given from the experiences of the known. Henceforth the results of this research will help children who are disable in four different ways; - envision new options for policy makers to adopt, come up with new ideas Non-governmental organizations and other stake holders can rely on, it will also be used as a resource base for practitioners to decide on priority requirement and school administrators will use the information from this research to improve on their planning

\section{Literature Review}

\subsection{Relevant Analytic Literature}

Policy Implementation Theories

The discussion of policy implementation is not complete without the prior knowledge of what policy is viewed in relation to policy implementation. R. E. Elmore, (1978) describe public policy as a sequence or design of government actions or verdicts designed to remedy specific social problems. On their part Palumbo, D.J., \& Calista, (1990) observed public policy as a focused course of action design by the government for a person or a group of people to follow in dealing with a problem or matter of concern. they added that success of any public policy is usually positively correlated on how it is executed, as such public policy need to be 
well implemented for the citizen to gain from the program. Further they informed that policy implementation is a part of policy cycle which is concern with the way government execute and satisfy a specific assignment. Many more studies Hill Michaell \& Peter Hupe, (2002); Van Meter, D. and Van Horn, (1975); and Howlett, Michael, (1995)have aired the same view that policy implementation can manifest itself in different arrangements depending on societal culture and institution background.

Pressman J L \& Wildavsky A, (1973) viewed implementation as a technique where set goals and actions interact for a purpose, Mazmanian, D.A. and Sabatier, (1983) regard policy implementation as a way of carrying out elementary policy decision typically merged in an act, or in an important executive orders or court verdicts. On side part Meier, O'Toole, \& Jr., (2003) explained policy implementation as what comes out from the government intention and the impact it causes. Elmore, (1978) came up with a more elaborate meaning by giving four complements for effective implementation (1) clear tasks and objectives (2) proper management plan (3) objective way of measuring subunit performance; and (4) a system of management controls and social sanctions. He added that implementation fails because of lapses of planning, specification and control. Similar idea was echoed by (Lasswell, 1970) but in a different fashion, claimed policy implementation can be administered in seven stages; intelligence, promotion, prescription, innovation, application, termination, and appraisal. Thomas R. Dye. (1976) summed the idea of policy implementation as the whole idea that involves activities to make policy achieve what legislators enacted.

In whole policy implementation is a very important stage in policy making process since the whole implication of it is the execution of law, where many stakeholders and institutions work as a team by the help of procedures and techniques to make sure policies achieve their intended goals. Therefore implementation is rather more of a process, output and outcome and require some control from the same actors (Pressman J L \& Wildavsky A, 1973; and Stewart, J. J., Hedge, D. M., \& Lester, 2008).Tracing exactly what policy implementation theory is can be a tall order given that a good theory need to have the following characteristics; unique, parsimonious, conservativity, generalizability, prolificacy, consistency, empirical riskiness, and thought. Wacker, 1998 and McCool, 1995) claim policy theory is unlikely to have all these and may contribute to lack of having an outstanding theory. Lester., Bowman., Goggin, and O'Toole, (1987) however observes policy implementation to have gained from classical theories over duration of time resulting to different theoretical models and approaches commonly applied referred to as top down and bottom up. The idea which was later supported by (Stewart, J. J., Hedge, D. M., and Lester, 2008)

\subsection{Top down Theorical View Point}

This perspective assume policy goals can be stated by policy maker, and implementation be carried out given certain mechanism, it emphasizes the role of policy maker as the one with overall authority and control over the environment. (Palumbo, D.J., and Calista, 1990; Younis, 1990; Van Meter, D. and Van Horn, 1975). However, Mazmanian, D. A., ad Sabatier, (1989) study concurred with earlier studies by Pressman J L \& Wildavsky A, (1973) that observes success of policy implementation depends on the actions and feeling of executing officers 
and the target groups in response to goals enlisted in an authoritative decision. Hogwood, B.W. and Gunn, (1984) while supporting the same went further to enlist characteristic of top down theorical perspective to include; policy decision is made by policy maker, its starting point is usually statutory language, structure is very formal, process is purely administrative, authority is centralised, output/ outcome is prescriptive, and discretion is top -level bureaucracy.

In another study Matland, (1995) observes the top-down approach to focus on official navigation of problems and factors, which are easy to operate and lead to centralization and control. On the his judgement, Elmore, (1978) perceives operation of top down approach to focus on funding formulas, formal organization structures and authority relationships between administrative units, regulations and administrative controls like budget, planning and evaluation requirements. Equally Winter, (1990) adds top-down approach relied more on political decision, law, follows implementation through the system, and advise is geared towards how to structure the implementation process to achieve the purpose of legislation.

\subsection{The Bottom up Theorical View Point}

This view point dwells on both formal and non-formal relationships in making and implementing policy. Howlett, Michael, (1995) regards this theoretical concept with the understanding the society, more specifically individual conduct. In his own studies and coining the term street-level bureaucracy' Lipsky, (1980); and Lipsky, (2010) propagated for flexible verdicts be accorded each field workers in relation to individual citizens when they are delivering policies to them. Hogwood, B.W. \& Gunn, (1984) while contributing on the same identified what they considered outstanding characteristics of bottom up theoretical perspective as; Policy decision maker under bottom up is done by street- level bureaucrats, starting point is social problem, structure both formal and informal, process is done through networking, including administrative, authority is decentralization, while output/outcome is descriptive, and discretion is bottom level bureaucrats. Other scholars Elmore, (1978); and Winter, (2003) notes discretional role of bottom level bureaucrats is challenging, more so as essential actors in implementing public policy, there is need to ascertain where the discretion is assembled, and which organization's repertoire of routines needs changing. Hjern Benny and Hull Christopher, (1981) support bottom up idea of networking as a process one, claiming that the approach accommodates many actors and analysis include many policies. He was however, concern with the way of identifying networks and suggested a snowball and socio-metric methods. Matland, (1995) however elaborated that program success majorly depends on skills of individual in local implementation structure given that central initiatives are not well adapted to the local condition

\subsection{Other development for Successful Policy Implementation (Hybrid approach to policy performance)}

More concern about how best policy implementation can be successful has captured another vital approach refer to as hybrid; which aims at informing how outcome of implementation can influence central and local level (Goggin, M. L., Bowman, A. Lester, J., and O'Toole, 1990). This approach is more scientific than the other two. It puts more emphasis on 
operationalization and testing of hypotheses Pulz, H. and Treib, (2007). Above all it focuses on self-explaining models to approach implementation performance. The models are identified as rational, management, organisational development, bureaucratic and political models.

Relevant hypotheses have been formulated as per each model with related variables; Rational model advocate for clarity of policy goals, target and objectives, accurate and consistent planning, clear and detailed task assignments, accurate standardisation, and proper monitoring. Management model is interested in; sufficient and effect use of budget, right organizational structure, quick, clear and two ways communication, involvement of people as co-producers, adequate equipment and appropriate technology, and correct location. Organizational development model is concerns with effective leadership, motivation, engagement of people, team building, and accuracy of decisions. Bureaucratic model on the other hand forge for; proper discretion of front line implementers, competency of front line implementers, control of the behaviour of front line implementers, and commitment of front line implementers. And final pollical model is concerns with variables such as avoid complexity of joint action, higher bargaining capacity, harmony among political actors, active political motivation, and minimizing the influence of pressure politics (Pulz, H. and Treib, 2007; Chandarasorn, 2005; and Anisur Rahman Khan, 2016)

\section{Empirical Literature}

\subsection{Development of Disability Policies on Access to Education}

The right to education is internationally acknowledged as principal human right and essential for sustainable development irrespective of one status, physically or emotionally. A number of international standard-setting instruments have come out strongly to protect fundamental human right to education (UNESCO, 1990; UNESCO, 2010; UNESCO, 2017). Access to education has been a major concern, more so for school age children including those with any form of disability (UNESCO, 2015; Mtuli Tellah Charles, 2015; and Muiti, 2010). Studies and reports have revealed that disabled people under go some different problems while in school system, this result in massive dropout and calls for particular measure to support maintaining them in schools, countries are encouraged to formulate and implement policies which are inclusive and can embrace all learner (RoK, 1993; Somerset, 2011; and Crosby, 2015). The influence of the 1948 Universal Declaration of Human Right rates education as a basic human right and a clear international indicator for policy makers all over the world. The declaration pushed for all member countries to come up with and implement policies which are non-discriminatory in education provision to any type of a child regardless of one's status; disability, ethnicity, religion, gender, capabilities among others (UNESCO, 1989; UNESCO, 2003; and UNESCO, 2015).

Muthili, (2010); and UNESCO,(2015) put it that world declaration of Education for All, (EFA) in 1990 and adoption of the United Nations Convention on the Rights of Persons with Disabilities. [CRPD], (2006) emerged as a great achievement for those who had interest in attainment of education, more significantly the target was people with disabilities (deaf and mute, visually impaired/ blind, any form of physically impaired) who could not access 
education. In essence the declaration of 1990 gave chance to all people, children, youth, and adult to benefit from basic education, this idea was hallmark as it enhanced access to children irrespective of their status Report from UNESCO, (2009); UNESCO, (2014); and UNESCO, (2015) and studies from Polat,(2011); and Wanjiku, (2012) tell that. declaration together with adoption CRPD, 2006, has proved very important for deliberations of policies concerning disability access to education curriculum and environment infrastructural facilities need globally, regionally, and nationally. UKaid, (2015) report specifically identified United Kingdom, [UK] government as one of the nations to abide by CRPD, 2006 report and ratified the CRPD policy in 2009. Canada too followed suit by effecting human rights act as a response to EFA declaration, 1990 and adoption of CRPD, 2006 which availed opportunity to prohibit various discrimination due to racial, religious, ethnicity, age, sex and disability. Canada went further formulating education act addressing proper space for disable students' requirements (UNESCO, 2015; WHO, 2011; World Health Organization and World Bank, 2011; UN, 2015; and WB, 2015).

Greece, Sweden, Australia, Ireland, Romania, and Russia introduced policies which were friendly to disable people to prioritise their access to education. The policies advocated for free inclusive and quality education for everyone with serious implication more so disable children. Facilities were provided, teachers trained, awareness campaigns enhanced, and research on new technology introduced. Also, these countries made several amendments on their policies to give more financial support and develop different programs to make access realistic to learner. Ireland was among the first one to develop special needs act in 2004 even before adoption of CRPD in 2006 (Kavouni, 2016; Clerke, 2015;Beamish, W., Meadows, D.,\& Davies, 2010; Watson, 2009; Foloştină, Duţă, \& Prăvălici, 2014; Zvoleyko, Kalashnikova, \& Klimenko, 2016; Louise, 2013; Karr, Valerie L.Edema, Ashley van Sims, Jacob Brusegaard, 2017; Callan \& Ed, 2018; UNESCO, 2015; WHO, 2011; and WB, 2015).

Iraq government did not only come up with policy for access to education for learners living with disability but embarked on broad based education system integrating children with special needs. Policy content included involving community provision to needy people irrespective of physical and mental status (WB, 2015; and UNESCO, 2015). In Middle East and North African (MENA) countries public policies have not so far promoted conducive environment for disabled people despite EFA declaration and CRPD, 2006 adoption. In MENA over $95 \%$ of disabled learners were excluded from participating in all levels (Bulat, 2017; and WB, 2015). In Tunisia however, conditions are different given the fact that the government policy as per tenth development plan (2002-2006) emphasized on supporting inclusive education for disable learners by providing needed resource.

In Jordan policy regarding access to education by disable learners partially adopted their requirements, Egypt policy on access to education however excluded disability from public schools due to their misperception of people with disability ability regarding social factors. Other countries such as Saudi Arabia, Senegal, Ghana, Ethiopia came up with policy in response to disability access to education which geared towards increasing learning institutions for disable children, training more teachers on special education, addition of more facilities, reinforcing head teachers support, and enhancing collaboration among school 
staff and between parents to help disable learners realise their competence (Anthony, 2009; Ibrahim, 2013; Alothman, 2014; Villenas, 2014; WB, 2015; and UNESCO, 2015).

South African education system borrow from a remnant inherited system of segregation left by colonizers, however the start of education policy on special need was a direct rejoinder to 1996 Act number 108 which was a vow to EFA as per UNESCO Salamanca statement of 1999. As such, South African government came up with education white paper 6 as directorial form of implementing document for inclusive education. In essence, white paper was meant to alter the country's education system by making a curriculum favourable for all disability learners needs including well trained staff. In reality the policy in south Africa advocated for disable education curriculum which is not only concentrate on academic but also in emotional and social perspective (Callan \& Ed, 2018; Louise, 2013; Glaser \& van Pletzen, 2012; Moloi \& Motaung, 2014; Muthukrishna, Nithi; Schoeman, 2000; Donohue \& Bornman, 2014; and ELSEN Directorate; Department of Education, 2001). Ethiopia policy which was adopted in 2006 reinforced awareness campaigns to sensitize stakeholders on disability development strategies in the society given the overlapping traditional values, a deep sense of spirituality and communal kinship responsibilities which was rooted. In parts the policy enlisted ways to help disable children by ministry of education developing manuals for teacher, coming up training institution, including special education need were prepared to support increased access (Tefera, Admas, \& Mulatie, 2016; and UNESCO, 2015).

Access to education by learners living with disability in Uganda was voiced under Articles 35 and 30, these articles not only gave authority for education to individuals living with disability but also empowered disabled children by providing equal opportunity to recognise their potentials (Najjingo, 2009; Moyi, 2012; and Republic of Uganda, 1995). Tanzania's, education policy changed to favour learners living with disability after world conference declaration and adoption of CRPD in 2006. The policy was designed in such a way that education implementation programs considered a wide diversity of requirements for disable learners in respect to their access to mainstream schools, physical environmental and child-centred pedagogy capable of meeting varied types of disability needs (Mtuli Tellah Charles, 2015; and The United Republic of Tanzania, 1995).

In Zimbabwe, Uganda, and Tanzania policy on discrimination for children with disability was put in place allowing disable children to access education. Education act in those countries inserted teacher uses favourable teaching methodology for learners living with disability in schools to include sign-language, demonstrations, illustrations, and use of varied instructional materials. Data to ascertain the number of disable children was also enlisted as a need to improve access (Mapolisa \& Tshabalala, 2013; USC. Republic of Zimbabwe, 2001; Musengi \& Chireshe, 2012; Musengi M, Ndofirepi A, 2012; Marcella Deluca, Carlo Tramontano, 2014; Moyi, 2012; Child Reach, 2016; and Mtuli Tellah Charles, 2015).

In Kenya the concern about learners living with disability started taking route way back with independent commission referred to as Ominde commission, the commission advocated for skills by training personnel to take care of disable people in schools (RoK, 1964). However, in 2003 another remarkable achievement was realized when Kenya enacted disability act, 
2003. The act offers legislative framework for access and inclusion for disable learner across all types. The key provision of the act was enactment of Kenya National Council for Persons with Disability (KNCPD) with the key obligation of delivering disability rights inclusive of privileges and protection (Kett, 2012; RoK, 2010; and KNHRC, 2014).

Apart from these development, Kenya serves as a member of many other international organizations which are supportive to disable learners accessing education (the African Charter on the Rights and Welfare of the Child, the African Charter on Human and Peoples Rights, CRC, ICCPR, and ICESCR). (Wanjiku, 2012; and Nyambedha, Wandibba, \& Aagaard-Hansen, 2001). More importantly the Kenya constitution, 2010 gave new dawn for marginalized members of the society disable learners being one of them, article 54 (1) (b) of the constitution provides for the right of PWDs to access institutions of learning and required facilities be integrated to suit their need, section 18 (1) \& (2) provides for inclusion and spell that no learning institution shall deny any disabled child access because of his status (RoK, 2010; and Constitution of Kenya, 2010). In trying to reinforce the plight of disable people in general and more importantly acquiring education, Kenya government has put in place some policies including;- disability policy; special needs education policy; national social protection policy, and draft human rights policy (Republic of Kenya, 2011; Republic of Kenya, 2001; Gok, 2010; RoK, 2010; KNHRC, 2016; KNHRC, 2014; and Republic of Kenya, 2007)..

\section{Methodology}

This study followed interpretive approach theoretical paradigm. According to Kelly, (2006); Terre Blanche. M., \& Kelly, K. In M, (1999); and Egon G. Guba, (1990) this approach is founded on the basis that people can understand others experiences through interaction and listening to what they say. Patton M, (2002); and Andrews, Squire, \& Tamboukou, (2015) support the idea and argue that interpretive paradigm is a more flexible research, sensitive, and suits complex issues. Lucianna J. Basilice, (2015); Nathan J C, (2011); and Fritton, (2009) emphases the fact that interpretative paradigm attach meaning to what peoples experience in context they found themselves, i.e. values of a phenomena do change from an individual to the other, time to time, and situation to situation. The method was found to be more conducive in understanding learners living with disability in Kenya's two counties Siaya and Kisumu. In-depth interviews, and dairy reports were used to collect primary data from key informants while Secondary data was gathered from journals, researches, conferences, policies, constitutions, and reports. Data was analyzed after going through various stages; coming up with codes, providing themes, revising themes, name themes, finally coming up with a report.

\section{Data analysis}

Individual was used as a unit of analysis to get views from lived experiences of the respondent. This is in line with Rubin \& Babbie, (2015); Patton \& Cochran, (2010); and Catherine; Marshall \& Rossman, (2011) who suggested qualitative approaches to focus on individuals, but can also centre on groups, organizations or processes. In this study, learners living with disability, their parents, teachers, principals and education officers in charge of 
special education served as a focus of inquiry.

\section{First Group Participant - Learners Living with Disability}

\section{Participant A; Jacky}

\section{Overview of the Participant}

Participant A, whom I called Jacky was a girl in early teen age, studied at Nico Hauser special secondary for the visually impaired. The school is situated in Bondo, Siaya county. I interview the student in one of the classrooms in the school compound. I noticed the girl could not see totally but had good sense of notice, and recall, had a walking stick to guide her movement.

\section{Experiences during Childhood}

I was born blind, my mother and other four siblings are blind, Jacky expressed herself openly, though some information was in her dairy report gathered two months earlier. The cause of my blindness is not known because my mother never took me to hospital. She however informed me that it was inheritance from the family gene. I have accepted myself that way and life seem normal to me. My childhood experience was not so good, I had to walk with my mother wherever she was going to look for food. Imagine, two blind people following one another with a stick! I had no friend; no toys other children are bought to play with, my family was poor. My father left my mother when he found all of us were blind. Jacky believes her father feared community beliefs with respect to disability.

Jacky stated how her early life was interesting but could not feel it so much because of age, I used to walk with my mother looking for food, sometimes we are given, at times abused, while, others could just through goodies at us without love. Jacky tells that; though I was young I could notice that was taking place, some receptions were just too poor but that was life then.

\section{Learning Environment and school life}

I was taken to a regular school by my mother, the idea was good for me because other sibling were in far school, so being lonely with my mother was not so good for me. Unfortunately, my mother did not know the expected documents required for admission, she just took me to school and left me there. I was sent back home by school administration to go for the documents, my mother could not find them and just sent me back to school, teacher had no otherwise but to allow me in school. The school was lonely to me, had no friend, teachers were not bothered about me but were busy with their daily curriculum which was more focused on normal learners, they were teaching without noticing that there is a blind person in the class. Children were only bothered to abuse and make fun of me. I had a poor in encounter.

Jacky narrates how infrastructure was not favourable; I had nobody to direct or support me, sometimes I could miss classes. Some rooms I could only reach when directed because I could not locate them with my walking stick. Jack recalls how her mother through local 
politician and influential persons supported her to get a special school. When I joined that school life as better but had to adjust, I had to learn to use brails, and accustoms to other visual learning requirement. I started getting formal education, and could now go to class with others, and be tested with exams. Teachers were good, I had companions both with students and teachers who were very friendly. I had people to share my problems.

At the secondary school, Jacky tells how all were even better; I joined Nico Hauser secondary school as grown up girl and knew what education is, I found school life good, I knew how to use learning facilities which could help me, I knew how to talk well and make friends, I also had experiences to share to help me make friends. Given that the school was a catholic sponsored, so many facilities were provided on top of government provision; I was able to use walking canes, brails, typewriters, and be guided by trained supportive staff. I find this school to care for the blind children fully, also am happy this school made me became religious, and through that I have made many more friends.

\section{Curriculum, government participation and Challenges}

I find some part of the curriculum not to be good with my disability. The routine involves, and structuring of learning gets me off due to timing. Most subject require me to have sight. Testing at the laboratory, mathematical symbols, agriculture, and home sciences practical are never friendly. I had a serious problem in my first primary school, teachers were concern with completing syllabus but not to make any special learner like me understand. In my second school it was good given that teachers were caring, and students too were friendly to sit and discuss what was taught in class. Mathematics was a big challenge, formulas were many. I could not understand, not see, this made my learning a bit impossible. Here at Hauser secondary school, the problem I have is with subjects which are practical oriented, explanations, and demonstrations pact, teachers also are not enough despite the available one trying to make us busy in all subjects. Looking at the government support Jacky tells that; the government has been so good to me I got assistance through some people, and since then my mother had never paid any fees or provided any need. My mom is relieved. I feel if more teachers and facilities can be added my education can be excellent.

In summary this is typical case where a disable child and the mother are interested in education but are not well informed. They get luck in disguise because of sympathy the mother gets from unknown people. Experiences also tell of social problem engulfing the learner, hatred, abuse, and community stigmatization. Her father had to succumb to social believe to run away from the family. Her experiences also tells curriculum challenges that affect blind learners

\section{Participant B; Norbert}

\section{Overview of the Participant}

Participant B, I will refer to as Norbert, is a deaf learner at Fr Ouderaa school for the deaf in Siaya county. Throughout my conversation with Norbert, I was assisted by sign language interpreter. My early childhood sometimes defeats me to tell because it a shame me, I was born in a hospital in Kisumu city, my mother tells me that I was born before time as such she 
took a lot of time in hospital to care for me. I was told that doctors tried to help me live but I ended up deaf.

\section{Experiences during Childhood}

The society was not kind to me at all, I was relegated to my grandmother since my father was against me staying together with them. He told my mother to get somewhere for to stay or she leaves the home also. My mother decided to take me to her mother's home where I got a new home. Am told, I started living with my grandmother when I was about one year old. My mother had nothing to do but kept on coming to support my stay. As I grew up I came to learn I could not talk when other children were communicating and laughing I was not capable of matching them. I was unable to attar anything only used my hands, and senses to talk and guide. Outside was hostile, I could sense when people were abusing me using wrong sign language to demonstrate their disrespect. I was not spared by even adults since some could hail stone at me as a sign of calling me when am a head of them walking. My grandmother was the only rescue I had, she could defend and make any sacrifice to make me happy. Being serious member of catholic church, she introduced me to church and it was only their I could feel welcomed.

\section{Learning Environment and school life}

The school befitting me was hard to come by near my locality, in any case nobody had thought such like school exist. I think my grandmother always had me in mind as far as going to school was concern. Through weekly catholic church group meeting called "jumuia" one day my grandmother got information from a catholic sister about a school suitable for me. My grandmother did not waste time by consulted my mother. who rushed to ministry of education for enquiry. I found myself into school system after such a process. In school feared from the in the first days, I was used to village life irrespective of societal view about me, I was used to it. However, in this school, I was amazed to find all children had some sort of deafness, this made me get relieved of stigmatization, the next problem was how to cope with routine school life, it was hard given favours I had from my grandmother only to come to rules and regulations slow by slowly I got used to it. After just a while I found school to be so comfortable, teachers were welcoming but inadequate to handle all our needs. Children were respectful to one another. I noticed some of my fellow learners' deafness were worse compared to mine. Each learner had at least a devise to assist mediate his learning. I passed national examination after studying for eight years in that school and selected to this school, where I find school life favourable like the one I had in primary. Am happy here learners are few not like my primary, there are sign language translators, teachers are very serious attending to learners fully even though they are not enough in all subjects' the school offer.

\section{Curriculum, government participation and Challenges}

Teachers are very important for my learning; some subject are totally abstract to me. When it is time for English or Kiswahili life sometimes become difficult because I cannot talk nor hear I rely on a translator and I had to know befitting sign language for a specific subject need. I don't understand why languages are part of subject am taught while I don't use them. 
Am always comfortable with subjects which are practical's, I have no problem with maths or sciences provided teachers explains and demonstrate them well. I am good in using my eyes, I can remember more and feel taught when lessons involve charts, formulas, and drawings. On government support, Norbert stated that; I think government support is prevent to me her in secondary school, in primary I was supported by a sponsor from catholic church. I however know government employ teachers and develop curriculum, which is also a support, however, Norbert notes infrastructural facilities and equipment as a major challenge in school. "I see less classrooms, hearing devises, and laboratory equipment. Equally teachers are major asset to my learning, but they are never enough to cover all lessons every day".

In conclusion Norbert experience shows how disable learners get wasted in villages due to lack of information and non-concern by the parent because of what the community attach to them. His experience equally shows importance of networking as a way of disseminating information.

\section{Participant C; STANLEY}

\section{Overview of the Participant}

Participant C, denoted Stanley is a learner in Saint George Special school in Kisumu county. I have no lower limb as you can see me seated on this wheel chair. I was born this way I think, I have never seen my parents since I was told that I was dumped on the streets. It was the police who found and took me to catholic nun foster home as toddles to care for me

\section{Experiences during Childhood}

My experiences were very difficult but that is a thing of the past, I relied on others in nearly everything, I had to be assisted to bath, wash my clothes. I was helpless with no sign of life. The laughs from other children was normal given that in that foster home there were some other children who had no disability. I recall children questioning why one should be done everything, is he special? I wish they knew what I was undergoing. I missed a lot as a child, I could not play, all the time I was left in the room when others were going out, sometimes I could be forgotten until I speak. I missed parental care only catholic sisters could carry me, some nicknamed me as angel. I used to feel so incensed when other children are visited by their relatives while I had none.

Living in a foster home has its own issues, children bully one another. I used to find it tough among the children who were assigned to help me. I remember being beaten one night because they were rained on while driving me back from chapel, I was also beaten one day for reporting some boys who stole some items in the room. I tell you my size could make me see funny things in our dormitory given that most children could not notice me being around. I was trusted by catholic sister who were managing the place, they took me as their first born given that children were coming and living after their relatives come for them. I remained because I had no one to pick me.

\section{Learning Environment and school life}

I learnt in a regular school next to foster home I lived, catholic sister in charge of foster home 
wanted a place I could be supported easily. Learners in this school were drawn from everywhere within the neighbourhood. Here I had very difficult moment, movement from one facility to the other required a lot of support, this was lacking though because school being next to convent some children could just come for support, others thought I was sisters' child, this made them give support. Throughout eight years I was in that school I depended on mercies from other children. I remember some of my fellow learners taking the role of wheeling me to various places within school compound as a routine. I made friends, and this was what made things work for me.

I think I started enjoying learning in school after making friends, though the school lacked environmental infrastructural facilities befitting me, other learners made me feel all were ok, they were treating me with a lot of sympathy, no one wanted to upset me, I was getting protection from all corners. It is funny that irrespective of the support I never missed some abuses which was however said with fear and when others were away. I was baffle how all learners just had some positive feelings to me without knowing my situation and background. It was amazing that teachers also loved me, my sitting place in classroom was known, and I was never punished when I am late for class or any school routine.

In this secondary school life is comfortable for me, facilities are available though not enough, learners are friendly and supportive. I think I have been lucky, everywhere I go am treated with a lot of sympathy, that is what make me happy in this world. People just offer me support even before hearing my side of the story, I usually get a lot of attention from teachers even more than my fellow disable learners. whenever I need assistance it has been so fast, learners also offer me support with joy. I am happy not all handicap learners in this school are wheelchair trapped like me, each has their own problem but, in many cases, they come to support me. I feel cared for

\section{Curriculum, government participation and Challenges}

Am a good student, there is no subject am poor at, but I have some specific subject which am never safe with despite passing them. When I was in primary all subjects were tailored well for my disability since much work was just reading. I however had a problem with the way school routine was scheduled. I was always late, assembly time was eight in the morning, that was not bad. I only had issues with lessons intervals and breaks I never used to have enough time to adjust, I was always late, and most of the time disturbing other learners because of my lateness. I also had a problem with sitting in class, whenever a tall person sat in front of me I could not see what the teacher was writing in front and will go without learning. I noted teachers in primary school I was were not all trained to teach somebody like me, some could be too sympathetic until I become guilty.

In this school I am encountering a lot of problems with some subjects, practical lessons are interesting for me but too risky. I need save chairs because I am small, I think curriculum should consider how efficient I can learn safely in the laboratory where there are chemicals and I need my safety. Tables are too tall, I cannot stand, my siting is curtailed whereby I cannot make movement properly on my on to control spatulas, Bunsen burner, and chemical. Agriculture is another challenge, I cannot dig because am fixed in my wheel chair, this 
applies to some practical found in home science subject. I think something need to be done to accommodate me.

On government support, I feel am a great beneficiary from the government, I am a live because of government and catholic church. I have been all along throughout my life been supported by those two institutions. I get food, accommodation and education because of them. I only suggest if more teachers can be added by the government, and infrastructure improved, I can be very satisfied given that apart from some issues I have with curriculum the way it in some subjects', the remaining subjects am one of the best in this school, and I know I will join university.

From what I gather from Stanley experiences, government is concern with its citizen regardless of their status, it also tells the importance of involving grassroot people to implement policy. His lived experience is a case that informs possibility that anybody has ability to acquire education provided he gets love and support.

Table 4.1. learners living with disability views on a sorted sub - theme

\begin{tabular}{l|l|l|l}
\hline Themes/ Names & Jacky & Stanley & Norbert \\
\hline Type of disability & Visually Impaired & Handicap & Deaf \\
\hline Nature of disability & Totally blind & No lower limbs & Total deafness \\
\hline Type support & Walking stick & Wheel chair & Interpreter \\
\hline Cause disability & Inheritance & Born premature & Premature birth \\
\hline Parental support & Minimal & Non & Minimal \\
\hline Parent awareness of school & No & No & No \\
\hline Society Acceptance & Not fully & Sympathy & Not fully \\
\hline Who give most support & Teacher & Teacher & Teacher \\
\hline Any other group support & Catholic & Catholic & Catholic \\
\hline Govt intervention & Early & Early & Early \\
\hline Experience with curriculum & Unfavourable & Fair & Unfavourable \\
\hline Infrastructure / Facilities & Inadequate & Inadequate & Inadequate \\
\hline Learning challenges & A lot & Moderate & A lot \\
\hline
\end{tabular}

From the experiences of three learners one can easily understand exactly what they go through and how. Policy makers and implementers can use this conversation to support their access to education by developing enabling environment. In all the discussion, teachers came out as very important in their life, however the way curriculum is structured seems not familiar, awareness, and decision making can be a remedy if well instituted.

\section{Second Group of Participant; Parents with Disable Children in Secondary school}

\section{Participant D; Roko}

\section{Overview of the participant}

Participant D, designed Roko, was a parent at Saint George School for the handicapped. I am a parent in this school, I also serve as a parent teachers association member (PTA). Am a 
university graduate and currently working in a private sector as a senior accountant.

\section{Experiences with the child}

I got to learn of my daughter's problem early enough, but I did not take it seriously, I can recall assigning her health problems to my wife as I was busy with my career. It was a small boil which emerged first, and it was not all that painful the way I could read from my daughter. The boil continued to develop though very slowly given that we were taking her to the dispensary to get some pain killers. In a duration of about one and a half year things were out of hand as it was now a wound. It was this time I got serious and took her for proper check-up, the result was not good bones had been affected and the best thing was the leg be cut. I was told the disease was infectious and could spread into other parts of the body. I complied for the leg to go though with a lot of pain.

I had to sacrifice a lot during all this time, I used my finances to see to it that my daughter was well, my wife took all her time in hospital with the girl, life was not easy since I knew I could not get support anywhere. After all was known that my daughters leg was going to be amputated I started thinking of what next. In the company of my wife I went for counselling, and we were told to make the child as comfortable as possible, and we were to accept living with her in that situation given addition demands. I remember first thing I did to my daughter was buying a wheel chair and so many toys. I was also told to give her good diet which I maintained. Later I bought her prosthetic legs. I did my best to follow doctor's instructions how to care for her and feel happy most of the time. I felt guilty and remorseful for attending to my career more than my daughter's health. When I realised she was passing school age my problem was how to prepare her. In my mind I planned for a regular school next to my home so that I could take care even while she is in school. I there bought her some pictorial reading materials, and a tutor was hired for preparation.

\section{School and community life}

It was sad my daughter was now growing old and I could not get a good school befitting her. I needed a school where I could totally monitor her health. I went to the nearby school however I was turned back citing lack of facilities and trained teacher in special education. The headteacher even suggested that I consider taking her to a special school where school routine was flexible. I however ignored him and went to education office where I was given a letter to take to him to admit my daughter without any condition. My daughter was henceforth accepted but life was not easy given that I had to take her to school every morning and get her back home every evening. Am happy in this current school am relieved, the child is in school well cared for I only come when called by the teachers, or when there is a meeting like the one I had today, I find school routine here is accommodative given the school is only meant for learners of her nature.

On community view Roko stated that, I rarely bother about what people say within the society about my family, they are not friendly to me because I don't believe in some of their views of seeing a witchdoctor to tell me what might have caused disability in my house, some tell me to marry another wife so that I can get rid of that omen. Am happy most children treat 
my daughter with a lot of sympathy.

\section{Support Acquired and Government Intervention}

It is only possible to get support if you have information, in a society where meetings are arranged without considering other people's program reduces chances of many attending. Here most meeting are never advertised well, and only few usual people attend and know them, it is unfortunate am not among those people. Over any support to her daughter, Roko tells that; I did not get any support from any quarter since I never used to attend most meetings. My community members did not support me but only tried to mislead, they have no respect for disability, they are always judgemental without even considering the cause of disability, I hated this. The grouping is the same, "disabled".

Over government support, Roko stated that; the government was so authoritative in my daughter getting into school system when the head teacher totally refused, I used education office which intervened, and I got a chance as I wished, I have never paid money as school fees, government has been doing it both in primary and secondary school here. Though I am supposed to be making some contribution to support school building for PTA kitty, most parents are never interesting in visiting school to attend to their children needs. Government and catholic church which is the sponsor has instead supported this school get build.

In conclusion the experiences of Roko informs the need to care for children health to avoid future complications, it also informs the important of being knowledgeable about the community, and general environment. The experience can be used by policy makers and implementers to involve everybody in decision making for rapid result.

\section{Participant E; Selly}

\section{Overview of the participant}

Participant E referred Selly, was a parent at Nico Hauser school for the blind. I am 48 years old, I can't speak English, only Kiswahili and kikuyu. I never attended any formal education. I was born blind, I think my blindness was hereditary given that my mother was blind and even all my four children are blind. I was married but my husband ran away after my last born, I have never seen him again. He used to think I could give birth to a child with no visual problem but when he noted the trend was the same he left.

\section{Experiences with the child}

When I gave birth and noticed my child was blind, I didn't bother much taking her to hospital or looking for any help. I knew the signs given that she was my third born. However, I was lucky my child did not have any health complication in any manner. I remember only taking her for normal vaccination which is meant for all babies. My child learnt most of the things through instinct, I recall her noticing most of the sounds, different peoples sounds, birds, animals etc. Her ears were sharp, and brain could recall most things even after sometimes.

I remember anytime I was walking with her looking for food, her instinct could make her judge very fast where we were yesterday or the previous days. I was always happy with her 
instinct. As young as she was my daughter could detect when people were welcoming or not, at times when reception was poor she could feel sympathetic to me. I can also remember that at a tender age she was good in following story. I used to call her my dairy and preferred moving around with her visiting than all my children. The other side of her was that she was noisy and quite engaging, most people liked talking to her because of those qualities.

\section{School and community life}

I had a problem for the first time my daughter went to a school, though some of my children are in special schools, I had never known how they were joining those school. I took my daughter to regular school to start learning, it was not easy during that time getting what to eat out of school for people like us was very difficult. I remember we were only two in the house, other children were in boarding school. I needed a place for my daughter to get relaxed, eat and come after lunch. My daughter by then had not reached school age but I took her to school to be feed, it was funny that I took her with no documents despite demand from the head teacher I was just adamant.

In this school my daughter suffered humiliation, she used to be abused, told all sorts of things but I told her to persevere, however it reached a point she was even being beaten by some workers, nobody bothered about her irrespective of her age and condition. I took her to another regular school and equally there was no much improvement, abuses were the same. Here even teachers were openly showing hatred. However, when she was rightfully in her school age I got her some support through influential people in the community. It was in that school my daughters learning became meaningful just the same way it is here in secondary school. Over attending meetings Selly sated that; In all those schools including here I don't attend parent meetings because people have attitude about me, others about my daughter, also in government schools' everything are provided, this is even a catholic school sponsored school everything are given to disabled people not poor parents of disabled learners to meet and be asked money. I can only come to visit my daughter know about her health status.

On society, Selly noted that, society is fond of gaging people, I am gaged in a wrong way people have a mindset about me and my children, though I am poor, the community give support with a lot of attachment, abuses are some of the compliment community offer, no respect. At times I feel am not a human being simply because of begging for my children to school.

\section{Support Acquired and Government Intervention}

I have been lucky to be supported a lot, I got food from the community, whenever I have no work and I look desperate people tend to assist me whenever I asked. My children have lived through good will of the society. I think talking is good, I even managed to get sponsorship of my daughter's education from people I simply traced and talked to anybody I feel can support or has influence. I remember it was through such a trap some people took it upon themselves went to the ministry of education and ask for my daughter's support to access education, and that is how my daughter accessed special primary school.

There are many instances I think helped me acquire education for my children, my movement 
from one house to the other looking for work and help made me know exactly what was happening in the society, all planned awareness meetings in the village I knew. I was able to know important people in the society and their impact in many issues. One could think I was only begging but I was getting to know a lot and that is what assisted me get my children special schools. I have gained a lot from the government through my children, I have been able to get most of educational support such as bursaries, and some other gifts from politicians to help my children. Education and children officers have been too supportive to me for my children sake, and in school, my daughter is loved by all teachers because of her performance. In most case she is given some personal support by catholic church sisters and teachers.

Experience of this parents tells how networking is very important, it also reveals how few people determine implementation of policies. What also comes out is that despite the society non-respect to disable people, they are willing to support them to live not to perish.

Table 4.2. Parent of learners living with disability views on a sorted sub - theme

\begin{tabular}{l|l|l}
\hline Themes/ Names & Roko & Selly \\
\hline Education background & Degree & Non \\
\hline When learnt of child disability & Small walking & At birth \\
\hline Societal view of the child & Mix & Beggar \\
\hline Awareness meeting participation & Non & Yes \\
\hline Awareness of special school & Yes & No \\
\hline Contact with Policy implementer & Yes & Yes \\
\hline School participation & Yes & No \\
\hline Support from govt (individual) & Non & Yes \\
\hline Support from govt (group) & Yes & Yes \\
\hline Any other group support & Catholic church & Many \\
\hline
\end{tabular}

From the two parents experiences it came out clearly that society has not positively welcomed disabled people within them, stigmatization is real and policy implementer need to do a lot of sensitization to the right people. Experiences from Roko and Selly tell how awareness meeting are not all inclusive, few people are usually invited for public meetings most people are left in the dark. Equally experiences revealed government serious role in supporting disable learners, it came out that government support is not selective more so for disabled learners in secondary schools. Discussion also reveals teachers as the ones making things to move in schools and so the decision they make is very important for access to education.

\section{Third Group of Participant; Special School Principals}

\section{Participant F; Richard}

\section{Participant Overview}

Participant F referred, Richard was a principal at Father Auderaa school for the deaf. Am in my late 40s, married with five children. I hold master's degree in special education and have 
attended some seminars related to special child. I am very experienced in teaching profession given that I have worked as a permanent government teacher for the last 23 years.

\section{School management Procedure}

Heading a deaf special school is not easy, I am expected to do a lot from the society and more so government. community expect me to understand the need of all deaf children without knowing some have many disabilities in one, others are so complicated that I have to study them as they learn in class. However, the main duty I do as a principal is mostly determined by ministry of education. Am entrusted to admit students to this school, which in the real sense is usually done from a central pool decided by the ministry of education immediately standard eight examination result are out. Admission is usually strict and thoroughly monitored by members from ministry of education supervising all steps they advise. Because not all learners selected usually report in my school, it is usually my responsibility to give report to the ministry in due time so that they can get replacements or advise me how to fill the gaps. Apart from admissions other responsibilities I have are well structured and is procedurally administrative. I make sure all teachers are working and providing evidence of their input, through schemes of work, lesson plans, and continuous assessment tests to learners. Most frequently I move a round school compound and classes to monitor learners' activities and teachers' involvement as per the school time table and daily routine. To help teachers become efficient I make sure they have teaching needs. To be sure whether I am in line with the good practices, as a principal, I usually work with ministry of education a lot to get their advice and request for any support. During national examination period life is never easy for me, I do make sure all examination papers reach school in time and returned to the strong room under police supervision immediate the examination is over. In co curriculum I try to assist my student to get playing equipment befitting them and participant in games as planned by the ministry.

My work is fully procedural, and most activities are schedule and open, it is not easy to work alone as a principal without teacher, my effectiveness depend on availability of teachers, funds and equipment's. here I lack most of these necessities, but I adjust with the little available since the school must operate.

\section{Parents and community participation in school management}

In this school I have over 80 children, meaning I should be counting on over 60 parents or guardians, it is amazing that those with children here are never interested in supporting the school in any form of development. In most cases I organise termly meetings with the parents per class only few usually attend. There is parent teachers association, (PTA) a body created under education act, this is never active since parent don't attend meetings. Worse of all annual celebration that I usually organise for gifts and to encouragement both teachers and student is also never honoured by parent, just handful do attend. In reality, parents are supposed to be part of school management, but here I manage with my teachers, many cases of indiscipline when a parent is called to come assist us counsel his child because of an issue, they decline to come. I think government regulation is to blame for parent poor participation, I am not allowed to send a child home, more so the disabled one, it is my duty to find means 
of solving such problem.

I have on the other hand tried to involve the community but is never successful too, in most cases when I give any member of the community an opportunity to supplies food items, and or a form of employment i.e. manual workers, they are never willing to do it full heartedly. The notion outside is that the school belong to government and they should keep off. Equally many times, when I have a problem with student sneaking out of the school compound they keep quite when asked or hide such students in their homes. Though the government expect that I work with community, it is never easy. Am always comfortable with a sponsor because it makes everything easy. In most cases I use church to mobilise for me the community wherever things are not working, and they must participate.

\section{Government role in school running}

The role of the government has been so useful to me as a principal given that everything is well set for me in a structured manner making my duty to manage only. I have a team of teachers who are employed by the government, these teachers teach learners on behalf of the government while following a curriculum which is also developed by the government. It is this curriculum that assist me to assign teachers lesson and direct them what to teach at a certain level. I totally rely on this document to assist me monitor my teachers and even student.

Parents in this school are never cooperative to assist me raise required development project, the government has taken upon herself to provide me with necessary funds to construct classroom and buy facilities I make a request for equipment funds and most cases I get after sometimes. Equally the government has made it easy for me to manage my teachers, I am always sent quality assurances officers to assess school curriculum and other school development, this make school running very easy since each one must adhere to government requirements to maintain his job.

In issues of exams I think the government has made it easy for me to only teach and then make its own assessment as per the curriculum by setting and marking her own examination to learners after every four years. My students are just taught after four years studying a summative examination is done, and its result that determines whether a learner qualifies to join university or be admitted in medium colleges.

In conclusion Richard experiences show how principals are entrusted with a lot of work in government policy implementation structure, there is need for parents and community to be made aware of their role, it however looks as though the government has monopolised school management.

\section{Participant G; Horrins}

\section{Participant Overview}

Participant G, I named Horrins, was the principal of Saint George special school. I am in my late thirties, my initial training was to teach in primary school, however I went back to study at the university and earned a degree in special education. Currently am doing master's 
degree still in special education. I have worked as a trained teacher in many schools starting from special primary schools, secondary schools, and now a principal. I have taught nearly all types disabilities in different special school.

\section{School management Procedure}

As a school manager my work is well programmed, I work using a curriculum which is well structured and is developed from ministry of education headquarters. To manage this curriculum, I mobilize my teachers every start of the term for a meeting then we distribute subject among ourselves following what one learnt at the university, or college. We then come up with overall timetable to show the distribution in terms of teaching time and class. This time table is kept in my office and staff room, it is from this timetable each class make its own. I can say what assist me manage teachers and student is this time table because it reflects what curriculum want and makes both teachers and student busy.

I also do involve teacher in my management as a principal, this I also do as per the regulation from the ministry, my deputy assist me in all matters concerning discipline and supervision of curriculum, then each teacher I assign one or two weeks to be on duty. It is through a teacher on duty learners are well managed and even visitors are well attended. Other procedure I use to manage is through class teachers whom I do appoint for each class to take care of class activities including register.

In my school here, I do have a forum how student manage themselves; that is through their own body referred to as prefects, each class has its own class prefect, dormitory, and even clubs, all small student gathering units have their own student representation. I find using that ministry structure to help me a lot making the bulk of work entrusted to me be decentralised.

\section{Parents and community participation in school management}

I find it had to involve parent in running school affairs, they are never their and for those who come their contribution are usually minimal because of lack of knowledge of school system. I must follow procedure as per the structures in places, these cannot be changed by parents meeting. I usually have class parents meeting scheduled termly, for them to air their views and assist me manage, it is interesting that many do attend, but their interest is usually centred on their children health, with no of very little contribute in curriculum.

My school parents are good in attendings meetings but when there is a project that require parent teachers' collaboration, they just accept but later no action is evident even if I try to follow up by the help of my PTA chairman. The problem I have is feeling within parents that they are poor, and their children need a lot for their personal support from them, and only need to concentrate on them. Others feel government gives a lot of money and they need not to contribute. The fact of the matter most of my parent are mostly guardians not real parents as such their attention is never in school fully. Apart from parent who are also members of the community, I find it equally hard to involve the neighbourhood community because of the way they perceive disable learners. Some feel bad to work in my school, simply because it is for handicap. Others fear anything government is involved to be so involving and can make someone be taken to court in case of a problem. I however have board of management (BOM) 
which is very supportive, I mostly make my request to the community through them. Being a ministry organ(BOM) has been very active in supporting me request for funding and managing various projects.

\section{Government role in schools running}

A school is part and parcel of the government. In my school I can say government role starts right from registrations. It is the government through ministry of education all school get registered. I find this to be one of the major roles. Also, in this school just like in others, the government has a well-established framework of how school is management, that is management through a well-developed curriculum, monitored by ministry of education officers who visit my school often. Am also provided with several management tools by the government example; teacher, finances, equipment. Though I work for learners, they are equally provided by the government each year through pool selection. End of four-year examinations is also provided by the government as a control measure on me so that the ministry can judge my work in relation to curriculum and procedures provided.

From this participant experiences and knowledge in school management, the government is the owner of schools being that it gives registration, provides teachers and give children to join school through joint selection of form ones. Horrins experience reveal how all schools have a well organised procedure developed and managed by the government.

\section{Participant H; Jacinta}

\section{Participant Overview}

Participant H; design Jecinta is the principal of Nico Hauser special secondary school. I am a catholic sister, my first devotion is to God and his people, I studied in university, here in Kenya, and I have made some visits abroad for exchange program on special education. Apart from that I have been participating in seminars and works on how to better special children and other vulnerable members in the society. Am an employee of the government and have served in many schools both as a teacher and a principal.

\section{School management Procedure}

In my school here, everything is totally done on a routine basis, all activities are documented. I find cooperation of all stakeholder as what this procedure requires most. I depend on my deputy and teachers for smooth running of the school daily. Being catholic sister, my daily duty starts in the convent with a prayer, then go straight to the school compound to oversee students' morning private studies, also ask for reports of any irregularities from watchmen and janitors. In away my work is such organised and very predictive, the ministry of education determines how school routine is run, and it is usually hard to go against it given that all schools way of management is design centrally for easy of management by the central government.

I find school management in my case to be all about involving structures in place students, teachers, parents and ministry to do their rightful mandate, I have seen that work and even reduce my stress. It is fortunate that the procedure of teaching is there, curriculum to follow is 
stipulated and I have all templates of how government want things done this is what makes this school run.

\section{Parents and community participation in school management}

I find role of parents in this school to be big, but that is never the case, parent only visit the school when called because of child indiscipline, poor performance, or financial related issues, they hardly visit to make any positive contribution for teachers or ministry to improve on their children curriculum. In this school I try to follow government procedure on parent active participation through parent teachers' association however I notice a lot of lapses with PTA supporting management in school given that many parents of learners I have here are not real parents but just foster one as such tend to show less concern on school management. I have also noticed in this school some parents just fear coming to school because they dislike their children situation. I equally find the community more so school neighbourhood not to be so close to school for support. Most of the time some community members don't re direct my blind learners when they miss the way and get outside the school compound. Other members of the community tend to confuse my student to drop out of school so that they could be employed as home maid, or farm boy. The only joy I have is my BoM, irrespective of them drawn within the community, they are much more supportive.

\section{Government role in schools running}

Concerning government role in school management I think, it does everything since am here working for the government and everything is done through me. The rules and regulations this school follow is all from government. teachers who are custodians of the school properties, are directed by the government through policies, regulations, and circulars. The government decides where am posted, transferred or can interdicted me if it feels am not following procedures properly. I also find the government role in school management to involve supply of learners to school, pay their fees and decides through examination whether they pass or fail. To make learners comfortable I find the government supply my school with building funds, and finance for equipment required by learners to enhance their education. Finally, government uses their ministry officials to monitor and advise on curriculum implementations and good management practices in my school.

In conclusion lived experiences of Jacinta reveals how principal activities in school is determined by policy, she has very little power to change curriculum or design structure to suit her environment. It also came out clear that parents and community have no much role to play in management since they have no much power to make change on the implementation format. 
Table 4.3. Special schools principals views on a sorted sub - theme

\begin{tabular}{l|l|l|l}
\hline & Richard & Horrins & Jacinta \\
\hline Education background & Master & Degree & Degree \\
\hline Role in School & Implementer & Implementer & Implementer \\
\hline Decision making & Formal & Formal & Formal \\
\hline Parents role & Less active & Moderate & Less active \\
\hline Teachers role & Formal & Formal & Formal \\
\hline Society participation & Minimal & Minimal & Minimal \\
\hline Government role & Very active & Very active & Very active \\
\hline Infrastructure / facilities & Not enough & Not enough & Not enough \\
\hline Serious stakeholder & Church & Church & Church \\
\hline Nature of output/outcome & Prescriptive & Prescriptive & Prescriptive \\
\hline Structure of management & Formal & Formal & Formal \\
\hline Process of management & Administrative & Administrative & Administrative \\
\hline
\end{tabular}

Lived experiences from the three principals shows their role as implementer to be in respect to strict rules and regulations given and controlled by government through ministry of education. Experiences also reveals that though parents and community are supposed to be part of implementation, they are never active because of many factors more so social. It also came out that principals have no power to adjust or improve in school operational procedures or structure even if need be. They tell how decision making is important in most cases given the situation they are, teachers are usually relied on in decision making.

\section{Fourth group participant; Education Officers}

\section{Participant I; Mr Otunga}

\section{Participant overview}

Participant I, referred to as Mr Otunga, was an education officer in Siaya County. My profession is teaching, I trained as a primary school teacher, then did a diploma, went to university later for a degree, and now I hold masters. All my training has been in special education as such, I have enough knowledge on special education matters. Apart from that, I taught in many special schools both primary and secondary.

\section{Role as an implementer}

My role as an implementer is not easy since the ministry rely on me to ensure the routine and regulations in schools is perfectly done, as such I usually promote inclusive learning in schools and other tertiary institutions, do some Staff development by training teachers on new ideas as per government requirements, supervise curriculum, monitoring and advise schools on sports, games, and music, advise on use of physical facilities, identify educational and teachers needs for improvement, and monitor and advise schools on environment.

While doing this work, am always very particular on the curriculum and government regulations, most of my work is structured and I must give a report on all my activities and 
findings to my bosses at the ministry headquarter monthly. Usually key in my duty as an implementer are usually teachers' activities, both inside classroom and outside, seeing how learners are attended, and witnessing how facilities are utilized. This is never easy since I also must go by teachers' daily work plan, follow school regulation, and understand the school background etc. Irrespective of my role, teachers also understand my duty and know my parameter as per structures in place. I have no much power to make any change in a school's way of doing thing but can only advise or suggest on how I feel they should follow routine.

\section{Part of Parents and other stakeholders in school management}

I find school management to be well structured, administrative pattern is well-arranged. the principal with the help of BoM, is at the top followed by the deputy, teaching staff, prefect body and then learners. Parent usually feature in what is called PTA, parent teachers association. According to the school management I know this body to be fully recognised in education act, it has a role of helping school to come up with projects they feel their children need. I also know it is duty of parents to come with suggestion how they want the school to improve on academic performance, and to see ways of motivating learners. Also, in some occasion a parent can be invited to school by the school administration to assist guide on child discipline issues. From my daily work plan many schools don't effect the role of parents in their management, and that is always advantage to parents because they fear commitments, other parents simply have social problems.

I can say that stakeholders in school are many, sponsor is always the main one if you leave alone government, the sponsor tend to support schools so much, education act enlisted its representation in school management, Board of Management(BoM). They do a lot of things depending with their interest, some build school, others employ teachers, some even create awareness. Religious organizations have been so useful in that role of being a sponsor in schools according to the records I have. Other stakeholder are parents which equally education act recognise them by having the chairman of a Parent Teacher Association (PTA) as one of the (BoM) member. Local community is usually given a lot of honour by the act as stakeholder and are equally given a slot to sit in a BoM meeting.

In all I think parents and other stakeholders are recognised since they are made involved in our education management structure, the problem is most of them are ignorant of school management procedure, making their contribution to be substandard to assist us improve in policy making or implementation.

\section{Teachers and government activities in policy implementation in schools}

School is teachers home, they see to it that all programmes are successively as expected. whenever I visit any school I do inform the principal first, but even if I don't and decide to go to any school I will at least get a teacher within the compound unless it is a national holiday, this tells how a teacher understands his role. I find teachers to be key in policy implementation process, they teach learners, examine them, and most importantly ensure daily routine is successfully followed.

In a special school setup, I even find teachers to do a lot more useful; they are very 
instrument for learning of these disable learners by not only teaching but total caring for any type of disable child admitted, make sure such children gain from education system by whatever means. I find in some schools where facilities are not good, teachers guard these learners from any risk and advise on their health, this help retain learners in schools. Also, according to our government regulation, which is my work kit both in school and in the office, teachers' additional duty in policy implementation is to support principals in administrative duties, talk to parents, advise learners on career choice, and make them feel encouraged as leaders of future generation. I think teachers are key in our school system running hence core to education policy implementation

From the time I have worked for government as an officer, what I have noticed is that government is the pillar in all activities taking place in school. I experience several ways government role features; provides financial support for school running making implementation a reality. Employ teacher, and education officers who are in full contact with the learners. Also, I find government use other department to influence policy implementation, example I have participated in many intergovernmental meetings at my level to see how we can help disable children access education.

In conclusion, the participant experiences tell how his role as officer support access to education for disable learners given the advice and general supervisory assistance he offers. Teacher role emerges as key given that learners depend on them in all their school need. Also, it came clear that it is government who directs all other activities in a manner that influence policy implementation.

\section{Participant J; Mr Oduor}

\section{Participant overview}

Participant $\mathbf{J}$, nicknamed Mr Oduor, was an education officer in Kisumu County. I am in my early 50s, I taught in secondary school level for 15 years' before joining ministry as education officer in the year 2000, since then I have worked in different places though my main work has always been centred on special education. Currently am doing $\mathrm{PhD}$ in special education.

\section{Role as an implementer}

I am a government worker, more of what I do is implementation of what the ministry direct me to do through circulars, workshops, seminars, and education policies in place. My major role however is to assess and supervise disable learners, advise and support teachers on curriculum delivery, report data from schools to ministry headquarter, work with the community and other stakeholder to create awareness, and coordinate with other departments. The list of my duties is long since other duties in many times come through a circular from the ministry.

My work is well structured, and all that I do is well determined since I cannot come out with my own opinion to direct school to improve, but to advise carefully following the established rules and regulations. I only operate administratively and within the structure, what is hard I usually report to my seniors, and even some issues reported take too long to be work on due 
to bureaucratic issues and budget. As an implementer I have also management to work with some department. In one instance I can recall a teacher telling me of a father refusing to treat his child making her not to come to school, it also happened this very child was disable. Through my connection with children department, police, and health ministry, the parent was taken to court, charged and forced to treat the child and return her to school. That what I deal with at times.

As an implementer I have also tried to bring in team work among the people working under me, this ease my work, I use influence and activities of teachers, parents, and other stake holders to fulfil this. However, the ideas of implementing policy among some groups has not been easy given that disability in most communities are surrounded by a number myth. Society I find myself take a lot of offense when you start telling them about disable people access school, they don't take it seriously.

\section{Part of Parents and other stakeholders in School Management}

Parents as the provider of learners are so important in school management, I think education act is clear, I usually tell my head teachers whichever school I visit to use them in implementation, however I have noticed in many school's parents are only used to bringing their children to school and provide financial assistance in one way or the other. In school management procedure according to ministry requirement, parent teachers' association (PTA) is supposed to be very active. I know all schools have parents, and teachers I don't understand why many parents tend to opt out in this engagement while they are expected to be very powerful. I however know that with the school curriculum and ministry expectations they have limits in some areas but not all.

I have always expected parents to work very closely with teachers for smooth implementation of curriculum, I have experienced situations where parents offer moral support, learner tend to get motivated both in academic and extra curriculum activities, teachers also do feel part of and parcel of the school where unity is. I have cases where parents participate in building school projects, meet regularly and motivate teachers impact in learners' disciple and high performance.

Other stakeholders also have different role in management, I find surround community as important, my experience with ascertain school working with the surrounding community was abundant harmony, peace and rapid development. The education act allows members of the community to take part in management as BoM member, it is through this they support school implement policies. Also, in our new political dispensation, I find working with local and national politicians as important since they influence a lot of development projects in schools given decentralization of funds to both constituency and county level. In education act, the law equally allows us to involve politician in board of management as members. These people in my opinion, sponsors included when properly involved tend to influence thing in school system for policies in place to be implemented rightly.

\section{Teachers and government activities in policy implementation in school}

For proper running of school and smooth implementation of policy in a school system, 
teachers are very important according to my experience as a teacher and now education officer directly working with them. I find them as the main implementers of education policy since they teach in class as per government syllabus, keeping peace among learners, motivate them, support disable daily needs, coordinate support staffs, assess equipment for learners' daily use, set and mark exams, discipline students' offenders etc. As education officer, I know the main aim of education is provision of knowledge and skill to learners, education policy is all about learners, knowledge, and skills and teachers are at the centre of policy implementation to observe all these. Teacher in special schools not just like others but have a special skill of giving knowledge to the special learners however most procedures are the same in school all over the country.

I also find teachers activity in policy implementation to be stimulated by the government. they are offered trainings, and necessary support, advised on their daily work by us education officers, and frequent reports to the ministry on extent of implementation. I find government activities to be encompassing because it sets the ball running by formulating the policies, create departments, and develops mechanism how to achieve them. In real education policy implementation is determined by the government activities from the beginning to the last example, it comes up with curriculum, create structures, funds it, employ personnel, bring learners to school, pay fees for learners, then set goals. All these activities including supervision and advisory role.

In conclusion $\mathrm{Mr}$ odour experiences tells how the work of education officers is very important and it is through them government get feedback from the real implementers who are teachers. Equally he revealed that the way education policy is implemented is well structured that nobody in the line of administration can change anything before the top decision makers come up with another design. The experience informs that implementation of policy is more of government role, others are just invited.

Table 4. 4. Special schools' education officers views on a sorted sub - theme

\begin{tabular}{l|l|l}
\hline & Mr Otunga & Mr Oduor \\
\hline Education background & Master & Master \\
\hline Role in School & Supervise Implementation & Supervise Implementation \\
\hline Decision making & Formal & Formal \\
\hline process & Administrative & Administrative \\
\hline Major stakeholder & Government & Government \\
\hline Parents role & Big & Big \\
\hline Government role & Active and structured & Active and structured \\
\hline Other stakeholders role & Many. sponsor Controlled & Many. Sponsor Controlled \\
\hline Teachers role & Formal and structured & Formal and structured \\
\hline Networking & Not structured & Not structured \\
\hline
\end{tabular}

From the experiences gathered from the two education officers, it came out that these officers work under tight program drawn from top. They assess teachers to ascertain government policy is implemented according to the curriculum drawn from ministry of education. It also came out that teachers according to the duties allocated to them by the ministry are the main 
grassroot implementer of education policies, they work in a formal and well structure manner with a total support from the government. The government role is however mentioned as very active and is the backbone to all happening in policy implementation. Experiences here also shows other stake holders' role is not well structured though they are recognised by the ministry, their participation is not predicable except the sponsor.

\section{Fifth group participant; Focus Group Discussion}

\section{Participant K; St George Special school}

\section{Overview, teachers' role, curriculum, and nature of learners}

The discussion with the six teachers in this school was done in a school board room, the highlights of the discussion revealed the following information. The school has only 9 teachers, all are well trained to handle special learners, it is however strange that not all teaching staff are permanently employed by the teachers' service commission despite the school having a population of 70 handicap learners.

The discussion over teachers' role revealed that teachers work is very crucial since they interact with learners daily to give knowledge and skills, as such their key role is to teach. However, the meaning of teaching teachers undergo according to this group discussion involve not only going to class but understand the syllabus which is developed from the ministry, making schemes of work, coming up with lesson plan, and making lesson notes. The discussion agreed that once they are inside classroom, they just don't just start teaching but try to understand learners' differences given most disable learners are very emotional. Teachers expressed their experience by saying that understanding a learner in the concept of handicap means proper exposition and use of well thought methods and apparatus. Apart from all that teachers said, did not forget to tell that they also form part of school administration, give guidance and counselling to both learners and parents on various issues.

On curriculum teachers agreed that it is the very important document in their work since all their planning on academics is centred there. Discussion also revealed that curriculum is a national document structurally formulated by the government to create uniformity in all schools in the republic. It reflects what each class should be taught yearly up to the fourth year, more so national examination is set following its content. Teachers discussed some hiccup handicap learners face due to uniformity of curriculum, and the way they are directed to use it. Infrastructure was mentioned, and inadequate teaching staff were mentioned severally.

The discussion expressed that all handicap learners are not the same the way they are treated, it came out that some learners have severe handicap problems while others are not so serious, the way they are treated in class depend with emotion the types of handicap displays. This call for more teachers and a befitting curriculum

\section{Parent role and school infrastructural facilities}

Teachers mentioned parents' role to be very crucial however, they are never seen most often when called upon, this applies to even in their yearly parent teachers' association gathering 
under the umbrella of PTA, very few parents do attend such an important meeting. The discussion also claim no PTA project had been planned for this year. It was clarified that though some parents come to school only to bring personal needs for their children, other parent had never stepped in the school compound since their children joined form one. Conversation heard that in this school, parent have not been supportive to motivate teachers or learners.

The discussion too mentioned that infrastructure is most crucial for all handicap learners in the school compound, though the school has some pathways, and classrooms, a lot is needed, we still lack proper buildings with ramps, elevators, and nice corridors with pillars. We also require good and well modified toilets not far from classroom as it is. On classroom, teachers feel they need to be a little bit spacious to accommodate wheel chairs, scratches, and free stretching spaces for whatever form of handicap. Laboratory and other building such as dining hall should have toilets extensions. On the same note teachers felt that learners from humbled background should be supported to get personal equipment to enhance their movement within school since some gadgets are old, others have permanent problems.

\section{Government activities and challenges in special schools}

Teachers listed many activities the government is doing to support handicap learners in their school as construction of modern buildings, employment of teachers, provision of curriculum, and inspection of schools. They also added government role of fees payment for the handicap learners.

On challenges teachers noted that though the government is trying to support schools, more attention need to be given to special school, teachers are very important for program implementation, lack of them is a big let-down for implementation success as such teachers mentioned the following as challenges; inadequacy of teaching staff, rigged class work and schedule, inadequate environmental infrastructural facilities, stigmatization, cultural believe, and delay of government financial support to schools. Teachers felt that government need to adjust curriculum for handicap learners because they are never first in their movement to compete with daily routine timelines

In conclusion, experiences from the teachers gives the insight of how a teacher is very important in policy implementation, however all his duties are regulated by the government bureaucratic system. Finally, possibility need to be established how parents or guardians of handicap learners can be brought into the mainstream to support schools in policy implementation.

\section{Participant L; Nico Hauser school for the blind}

\section{Overview, teachers' role, curriculum, and nature of learners}

The discussion with teachers in this school was quite interesting, they reported to be only 11 teaching staff, with about 120 learners of which about 80 were partially blind, and others had different complicated cases of blindness. Teachers revealed that all of them were well trained to handle special learners, however the number were less compared to learners. It also came 
out that only nine of them are employed by the government, others were on contract.

Teachers mentioned several activities they participate in doing while in school, they indicated how their work is well planned and regulated by the curriculum from the ministry of education, characteristically the discussion was informed that anytime a new term begins, teachers start their work with a meeting to share lessons as per subjects they were trained in colleges, draw time table on how they will be attending classes without clashing, also develop duty rooster where each teacher is allocated a week or two to be responsible for school running. Other duties the discussion mention included guiding learners in and outside classroom about career, attending to extra curriculum, disciplining offensive learners. They agreed that in education policy implementation, their duties are many but so much regulated by the curriculum and ministry requirement at any interval.

A look of curriculum and nature of learners was equally interesting given that discussion found curriculum to be too rigid on visually impaired learners. Teachers noted the occurrence different types of visual learners where some are totally blind, other can see if powerful devises are used, while few have a problem with light and sun, as such uses dark glasses. It is unfortunate that the curriculum is the same for all these learners. We must use brails and a lot of lecture, and because some don't use brails, we have to dictate a lot, meaning teaching time is always less. The discussion noted how teaching these learners consume a lot of time while school routine is programmed, and national examination time is the same for all learners in the country irrespective of disability. The discussion also agree that some subjects are not friendly for these learners, mathematics, and some sciences subjects were mention due to use of formulas and experiments involved, discussion noted the difficulties they undergo helping these learners to comprehend these concepts

\section{Parent role and school infrastructural facilities}

The discussion on parents' participation in this school was noticed to be minimal, despite the role the ministry attaches to them. Teachers expressed their low experiences with parent work in supporting them, it came out that, some had not visited their children since admission, most of them were not even coming for PTA meetings which is supposed to unite them as a school community. Teachers accused some parent of failing to come when called over their children indiscipline problems in school. They however consoled themselves that God has been with them being a catholic school, catholic father and sister principal have always supported them counsel students even if parent fail to come.

Teachers agreed that the school is trying to make learning friendly to these learners, they recognised improvisation of pathways, and sideways that guide learners to various destination within school compound, fencing of the school compound which notify learners their parameter and enhance monitoring their movement all the time. Member of the discussion however felt more facilities were needed to make their work easier; favourable lighting in all classroom, enough brails, personal equipment like walk sticks, glasses of different lenses and sun glasses were some of the requirements. 


\section{Government activities and challenges in special schools}

Teachers also discussed the activities of the government as per their experiences in the school to include; employment of teachers, deployment of principal, development of curriculum, supervision of curriculum, providing learners to schools, setting national examination, and making. Teachers also stated other activities as construction of buildings, and support for learners' personal needs. The discussion agreed that government activities make smooth running of the school since all programs and routines are formulated from ministry headquarters. Teachers also indicated that all government activities are formal in the way they are done, and the school must comply by giving regular report o ministry at an interval.

Teachers however noted that despite all the support they get from various quarters, they have several challenges which they identified as; Inadequate teaching staff, few equipment, lack modern technology, few buildings among others. They also feel syllabus need to improve to have all type of visual learners in mind. Parents need to be motivated to help them encourage learners to accept themselves the way they are, and finally government should provide adequate financial support to schools at the right time so that debts and laps in routine curriculum can continue without failure.

Finally, the focus group discussion confirms that teachers are very interested in their work, ready to help learners even under pressure of work load. Government routine programme need to be supported with proper facilitation so that teacher can find work easier. Provision of equipment and required facilities at the right time will solve most of the challenges teachers face. Parent need to come out forcefully to support in policy implementation.

\section{Participant M; Father Auderaa secondary school for the deaf}

\section{Overview, teachers' role, curriculum, and nature of learners}

Conversation with teachers showed the school have 9 teaching staff, 6 female, and 3 male, 84 learners with different kinds of deafness. Among 9 teachers 7 are employed permanently by the government others are on contract. Teachers also mentioned that they are all trained with different working experiences.

On their role, the discussion isolated the following as composition of what they do daily. Teachings learners using ministry provided syllabus, maintaining discipline among learners both inside class and outside, helping principal in any administrative work assigned, and guiding learners in outdoor activities which at time involve outings. Teachers also explained that teaching deaf learners is never an easy task, one requires an added knowledge of sign language apart from just interpreting normal curriculum.

On curriculum a lot of experiences were shared by the group members, it was agreed that curriculum used in school is more uniform to all learners with very minimal adjustment for disable people, deaf being among them. Teachers felt some of their classes are never effective because of the curriculum. They single subjects like English, and Kiswahili as among the subjects they find difficulties in teachings. Discussion noted that deaf people have their own language "sign language", that is what should be in their curriculum to be tested. Taking from 
experience, the group noted need to limit subject that require a lot of explanation for this type of disability, use of sign language should not be too much, because learners get tired without variation of teaching methods. They also stated that subjects such as history, geography, and others of that nature a very particular way of teaching since they require a lot of explanations. However, they explained that mathematics and sciences where practical and formulas are derived are favoured since a lot of the content can be verified by seeing.

The discussion noted different types of deafness, and all need different attentions in terms of teaching. Group talked of varied experiences where some learners can hear little, others are deaf and dumb, some can talk but cannot be heard well unless you use a devise etc, all these learners expect curriculum attention to acquired appropriate education. Discussion talked of school not minding about such differences but put them together and is usually upon the teacher to see what to do. Teaching such learners require different program, and enough teaching staff for them to acquire knowledge.

\section{Parent role and school infrastructural facilities}

The discussion with teachers clarified minimal parents' participation because majority of deaf learners in the school come from foster families, some lost their parents, other are neglected due to their situation, and how society view them. The discussion however agreed that parents are supposed to be very instrumental in supporting teachers more so in discipline matters, and career choice for their children. They are also expected according to government regulation to be meeting frequently so that they can help school administration in coming up with development projects, most parent in this school, the group noted not to bothered to come or associate with their children.

Over infrastructure, Teachers stated inadequate infrastructure for them to make learning effective for their students. They talk of experiencing some learners not comfortable because of the nature of classrooms which lack speakers to support hearing, good laboratory for science practical, and non-concern for each deafness learning infrastructural requirement. They stated over reliance on sign language interpretation as a substitute of facilities rather than embracing new technology to support learning.

\section{Government activities and challenges in special school}

On government activities the discussion mentioned experiences on government activities to be varied. They cited government activities to be supported by the policies which they formulate as such they; develop curriculum, train and employing teachers, supervise curriculum delivery, register schools, admission of learners, construction of school buildings, deployment of school principal and provision of financial support for daily school management. Equally discussion group mentioned government role of punishing teachers, and non-teaching staff in case of non-compliance, disqualifying schools in cases of examination cheat, and transfer teachers to where it feels his services are required best. They also mentioned government delegative role of financial management to BoM.

Teachers during discussion express the following challenges they experience daily as they encounter with learners; strict adherence to regulation/ curriculum, inadequate teachers, lack 
of environmental infrastructural facilities, social believes, inadequate financing, poor technology, lack of sign language interpreters, inadequate education officers to support supervision, and lack of support from other stakeholders.

In conclusion the discussion reveals need to consider different types of deaf learners in curriculum formulation, also employment of enough teachers and language interpreters can help reduce the problem of learners failing to cope in other subjects. It also came out that government has the overall power to make deaf children be in schools and be taught comfortably given the fact that they register all schools and admit children into school system.

Table 4.5. Special schools principals views on a sorted sub - theme

\begin{tabular}{l|l|l|l}
\hline & St George & Nico Hauser & Fr Auderaa \\
\hline Learner type & Handicap & Visual impairment & Deaf \\
\hline Teacher's work & Structured & Structured & Structured \\
\hline Curriculum suggestion & No modification & Less modification & Modification \\
\hline Parent role & Not seen & Not seen & Not seen \\
\hline Infrastructure/Equip & Very essential & Very essential & Very essential \\
\hline Major challenge & Infrastructure & Curriculum/infrast & Curriculum/inf \\
\hline Major stakeholder & Government & Government & Government \\
\hline Other stakeholder & Catholic & Catholic & Catholic \\
\hline Decision on curriculum & Government & Government & Government \\
\hline Process to improve & Administrative & Administrative & Administrative \\
\hline Decision they make & Formal & Formal & Formal \\
\hline
\end{tabular}

From the three focus groups discussions, it came out that teachers role are well stipulated and structured. The management is done under strict rules and regulation. Members also noted the need for curriculum modification to suit visual impaired learners and deaf, also infrastructural facilities, and equipment were mentioned as impediment for access. However, it was agreed that despite their role in implementation, any attempt to change anything in the curriculum may take time due to formalities involve and the way decision are made.

From the analysis of all the respondents who participated in the study, the following 8 themes were drawn for further analysis. Decision making, awareness, cultural beliefs, Curriculum, Environmental Physical Infrastructure, Teachers Role, Stakeholders/ Government Levels of Authority and Parental support

\section{Discussion}

\subsection{Decision Making.}

In policy implementation decision making is very important since it determines the success of specific policy. Discussion with participants highlighted how they make decision to implement policies in place. All the 3 principals indicated that all decision they make are formal. Also, the 2 education officers stated that all their decisions are usually well guided and formal. Teachers in the 3 focus group discussions noted the importance of decision making, and equally tells of how all decision they make are guided. Observation from the finding shows the level at which all principals have managed their institution is by making decisions as per ministry of education requirements. Teachers also mentioned the decision they make on their classroom duty is guided by the curriculum. In all the three focus groups, 
teachers explained their duties and stated how their success comes because of decision they make in dealing with issues. This concurs with Hogwood, B.W. and Gunn, (1984) suggestion that policy decision should be one of the most important characteristics of policy implementation, it can be done by policy markers or street level bureaucrats. In this a case we find most of the decisions made by teachers, and principals are done by policy makers. Looking at the original perpetrators of access to education by learners living with disability policies, the ministry of education action of dictating policy decision on implementers is not strange given that most countries adopted the idea from global bodies and several declarations UNESCO, (1990); UNESCO, (2010); UNESCO, (2008); and UNESCO, (2017) which in parts stated the right to education as internationally acknowledged and principal human right and essential for sustainable development irrespective of one's status.

Despite many counties following EFA declaration, 1990 and adoption of CRPD, 2006 which required education for all, and placed a lot of attachment on disable children schooling. A scholar, Lipsky, (2009); and Lipsky, (2010) is of the opinion of that street level bureaucrats should be free to make decision since their duties are routines which is self-initiated, plan strategies to handle uncertainties and work pressures. Discuss with education officers informs of strict policy decision that come from policy makers, informs their duty as to follow rules and regulation while supervising teachers, principals and checking school needs to forward the reports. The Government of Kenya, (2013); Government of Kenya, (2003); and Republic of Kenya, (2001). Elmore, (1978) and Meier, O'Toole, \& Jr., (2003) however argue that the ideas of policy decision coming from policy maker aside from street level bureaucrats makes government intentions and impact to be met as per their will.

\subsection{Awareness}

Barrett, Susan, (1981) argued that the success of policy implementation depends upon compromises between people within an organization. cautioned that policy should not be regarded as constant, need to be mediated by actors through mediation and modification. Awareness is very important denominator in policy implementation. Conversation with parent about awareness of special school showed both were not aware there were special schools in Kenya to support disable learners of different kinds. Learner also during discussion with them on whether their parents were aware of existence of a special school said no. Also, the knowledge of school meetings was discussed during the discussion with both parents, they claimed lack of information of any meetings by the authorities but were quick to say that even if they are told, they don't go because what they hear meetings are never participatory, all the agendas are normally set without considering anything outside what government officers have. Two learners interviewed also stated that they delayed in accessing education because their parents were not aware of schools befitting their disabilities. even added they were not aware the government gives support to disable children. These experiences can make policy makers to gain from Hjern, (1982) study that observed that policy implementation depend on relations between several different organizations, emphasized on networks as key to 'bottom-up' application, and advocated for structural formation to be within the pools of establishment. 
Access to education for learners living with disability policies can be effectively implemented if awareness is enhanced and issues to do with discrimination as per racial, religious, ethnicity, age, sex, and disability status are put a side. This is what has made counties such as UK, Canada, Australia, Sweden, and Ireland be more progressive in having their disable children in schools (UNESCO, 2015; WHO, 2011; World Health Organization and World Bank, 2011; UN, 2015; and WB, 2015). It seems Kenya situation replicate Middle East, North African (MENA), Egypt and Jordan where awareness is low making few people to know about educating disable children. Bulat, (2017); Anthony, (2009); Ibrahim, (2013); Alothman, (2014); and Villenas, (2014) and reports from WB, (2015); and UNESCO, (2015) however, claim the same situation is observed most African counties. Hogwood, B.W. and Gunn, (1984) however observed that policy should be implemented based on a grounded theory; cause and effect relation be direct with minimal interning links; single implementing agency with no support from others; proper understanding of the objectives; perfect communication and coordination; obedience for those in authority. His argument also borrows from Christopher Hood 1976 who claims that the only way of solving implementation problem is by instituting perfect administration to assist manage resources available and politics

\subsection{Cultural Beliefs}

Peoples understanding about other can affect policy implementation positively or negatively. Conversation with the two learners living with disability informed of the feeling the society bestowed on them, 2 of them talk of laughter, and humiliations of all sorts which greets them within the society, 1 states how he is only treated with sympathy and as helpless members of the society. All the 3 feel un safe within their own communities, among their fellow children and adult. both parents also feel the society is not fair to them, they are usually abused making them not to attend some meetings. two learners explained how their mothers were subjected to harsh conditions because of giving birth to them. This is very unfortunate given that the government through constitution and policies gives priority to vulnerable groups or individuals (women, older members of society, persons with disabilities, children, youth, members of minority or marginalized communities, and members of particular ethnic, religious or cultural communities) (Republic of Kenya, 2005; United Nations, 2006; RoK, 2010; and UNESCO, 2013).

From the discussion, the policy content is very clear the government only need to borrow some ideas from Barrett, Susan, (1981) who articulated that policy implementation need to depend upon compromises between people within an organization, the policy beneficiaries can fully realise the gains of policy if the society comprise and accept one another within their cultures. Many studies and reports UNESCO, (2015;) Mtuli Tellah Charles,(2015); Muiti, (2010); RoK, (1993); Somerset, (2011; and Crosby, (2015) have established school age children withdraw from school due to many societal problems related to culture and poverty. There is need to look for better ways of solving this problem. Mazmanian, D. A., \& Sabatier, (1989) idea can be of some help, impacting in implementation process to comprise issues touching on the manageability of the problem'; no statutory variables affecting implementation'; and capacity of the statute to structure implementation. 


\subsection{Curriculum}

Curriculum was identified by all respondents as very important aspect in access to education for learners living with disability. Out of 3 learners living with disability I shared their experiences, non-was fully comfortable with curriculum. Teachers in focus groups discussions had different feelings about curriculum following the type of disable learners they were teaching. Teachers from St George school for handicap did not see the need for modification, while the ones from Nico Hauser school for visually impaired felt some modification was needed to suit their learners, and the teachers from Father Auderaa school for the deaf were for more modification. Further discussion with teachers on curriculum revealed curriculum as ministry of education affair, their duty is to teach the way prescribed with no change at all. This situation teachers and learners find themselves agree with Bardach, (1977) who explains the need to deal with agents informally since they can only be brought together when collaboration is required given they are always committed to work. He further argued that implementation should be looked at as a game, advised those on top to care a lot when coming up with scenario writing process and usage while fixing the game. Kenya education system should learn by from Anthony, (2009); Ibrahim, (2013); Alothman, (2014); Villenas, (2014); WB, (2015); UNESCO, (2015); USC. Republic of Zimbabwe, (2001); Musengi M, Ndofirepi A, (2012); and Najjingo, (2009) studies and reports that identified education act in Saudi Arabia, Senegal, Ghana, Ethiopia, Tanzania, and Zimbabwe inserted teacher uses favourable teaching methodology for learners living with disability in schools to include sign-language, demonstrations, illustrations, and use of varied instructional materials as a way of making curriculum friendlier to disable learners.

Discussion with the three principals on curriculum matters was centred on their role which they mentioned as well structured and formal since their work process was purely administrative, argued that it was through strict adherence to the program that would enable them achieve output needed by the ministry. On the same, all education officers confirmed their duties to be formal and well-structured as such whatever supervision they carry out on teachers regarding curriculum is all well organised from the ministry headquarter and their duty is to see what teachers are doing is as per the regulation. The strategy used by Kenya ministry of education is however supported by (Pressman J L \& Wildavsky A, 1973) idea on policy implementation stating that the practice of implementing policy need to followed strictly as laid down in official documents..

The idea of having centralised curriculum given to learners living with disability tend to make some types of disable learners not to gain at all despite the government of Kenya through the constitution and policies in place giving new dawn for marginalized members of the society, article 54 (1) (b) of the constitution provides for the right of PWDs to access institutions of learning and required facilities be integrated to suit their need, section 18 (1) \& (2) provides for inclusion and spell that no learning institution shall deny any disabled child access because of his status (Republic of Kenya, 2011; Republic of Kenya, 2001; Gok, 2010; RoK, 2010; KNHRC, 2016; KNHRC, 2014; and Republic of Kenya, 2007). (Wanjiku, 2012; and Nyambedha, Wandibba, \& Aagaard-Hansen, 2001). 


\subsection{Environmental Physical Infrastructure}

Though all learners regardless of their physical status requires some environmental physical Infrastructural facilities, disable learners require them most. Discussion with learners living with disability reveals infrastructure and other facilities were inadequate in all school they were. Meaning they did not have enough support to make their learning comfortable because of less facilities. All three group discussion members agreed infrastructure were very essential for them to execute their duties, however they concurred with learners at some point that they were inadequate. Lack of infrastructural facilities have been a big problem affecting disable learning across many third world counties in Uganda, Kenya, and Zimbabwe studies by Najjingo, (2009); Moyi, (2012); and ; Muthili, (2010) point at big class size, lack of supportive infrastructural facilities, low teacher student ratio, poor resources in special and regular schools to support required disable learners needs as other related problems.

Infrastructural support is a very serious issues that can totally hinder curriculum delivery for these leaners. Van Meter, D. and Van Horn, (1975) noted the need to maintain conducting longitudinal approach in doing implementation, this they argue will support identification of relationship at one point in time. The following variables were seen key in their study; policy standards and objectives; the resources and incentives; the quality of inter-organizational relationships; the characteristics of the implementation agencies; the economic, social and political environment; and the 'disposition. Since getting adequate infrastructural facilities require some support, their idea can be of use for policy makers to solve this problem.

Discussion with the school principals also confirmed inadequacy of infrastructural facilities, however, education offices were careful not to discuss their availability stating their role is to inspect what was available, however they said government is the main provider of such facilities. Study by The DFID (2012) isolated use of existing laws, collection of adequate data and improvisation of environmental infrastructure as the best strategy to make disable learners' access education. Also studies by Frankel, E.B., Gold S., \& Ajodhia-Andrew, (2010;); Franke \& Guidero, (2012); Halfon \& Friendly, (2013); Fritton, (2009); and Geyer, Alexis, Putz, Jenni \& Misra, (2017) notes develop countries such as United States, UK, France, and Australia have developed and implemented their policies to accommodate environmental infrastructural facilities needs for all type of disability. They reported government commitment on financing for such facilities and constant research on disability livelihood improvement is always key in those countries.

\subsection{Teachers Role}

The work of a teachers came out loudly as key implementers of access to education policy at the lower level. All respondents had something to say about teachers, all the 3 learners indicated most support they get from school to come from teachers, parents also noted meeting with policy implementer who is a teacher, however all 3 principal regarded teachers as workers whose duty is very formal, education officers viewed teachers in terms of the role they play as formal and structured. It is interesting that teachers echoed same sentiment as education officer as they view their work as structured and formal. Going deep into what other participant had to say about a teacher role, all 3 learners spoke of being taught by a 
teacher despite other problems they face, teachers try their best to make them comfortable. Principal tells of teachers' role to be mostly guided by curriculum which they do as required, and on top help in school administration. Education officers says to interact with teachers only when they visit their school to supervise syllabus coverage, however teaching and others administrative work are part of their duties which are very formal and structured.

From the information gathered, teacher seems to be very important in access to education for learners living with disability and policy implementation process, they just need support to perfect on their duties. Good policy implementation design can support improved delivery, given teachers role requires a lot of flexibility to modify situations to suit specific disable learners situation given; curriculum has some inadequacies, lack of infrastructure and few support staff. Policy makers need to consider Michael Lipsky street level bureaucrats, bottom up theory to give them more authority. Lipsky, (2009); and Lipsky, (2010)observed street-level bureaucrats duties are routines which is self-initiated, plan strategies to handle uncertainties and work under pressures to implement public policy, advancement of ideals but process which is more practical, Lipsy argue that the street level bureaucrats adjust to work requirements, spend their work lives in service, believe themselves to be doing the best, develop conceptions of their work and of their clients. UNESCO, (2015); and WHO, (2011) reports shows teachers Sweden, Australia, Ireland, and Russia are well trained and has good working environment with all required facilities. This is unlike some developing countries where teachers work under strict rules and regulations while facilities are lacking, staffing is very un-proportional and payment is low. (Najjingo, 2009; Moyi, 2012; Muchiri, N. \& Roberson, 2000; Muiti, 2010; Chomba et al., 2014)

\subsection{Stakeholders/ Government Levels of Authority}

In school management many stakeholders do exist, their main purpose is to support schools in one way or the other to achieve its objectives, as such they serve as policy implementers. The major stakeholder in implementation came out to be the government. Learners made it clear that all of them got government support at ascertain level, all the 3 learners got support very early in primary level of education. Parents also noted government as very important, this was observed from all the 3 parents interviewed accepting their children getting support as a group, meaning while in secondary school, while one parent child gained from government while in primary. All the three-focus discussion confirmed government to be a major stakeholder in school running and funding. All 3 principals and 2 education officers also mentioned the government role in schools as active.

While discussing other stakeholders and their activities it was only the sponsor, catholic church that came out clearly as all the 3 learners could only identify catholic church to have given some support to them in one way or the other. In all the 3-focus group discussion, teachers recognised only catholic church as another stakeholder apart from the government. Principals too established catholic church as the only serious stakeholder which is more supportive after government. Both Education officers also stated sponsor to be more serious stakeholder in schools, they explained many existing stakeholders but in those three schools, catholic church was doing a lot. Education officer stated that even though catholic church 
assists much, their duties are controlled by the government. The three parents when asked if there any other group that have supported their children, one said catholic church, and another one said many. Though from the study it came out that there are some other stakeholders' PTA, BoM, politicians, and even human rights, their impact was not major since some were working alongside government officials.

Government serious involvement in policy implementation is not a strange thing given that support for disability education started long time ago right after independents. There have been several policy decisions and commissions created by the government to give direction on policy implementation for disable learners. Republic of Kenya, (1964); RoK, (1964); RoK, (1976); Kamunge, (1988); Republic of Kenya, (1999); and Kochung E., (2003) all advocated for having disable learners in schools, training of teachers, and establishment an enabling curriculum. The government since then has tried to make implementation reality by getting directly involved. This tend to agree with (Pressman J L \& Wildavsky A, 1973) who claims that the practice of implementing policy need to follow strictly relationship as laid down in official documents. They also supported the idea of linkage at all levels. Kenya government has come up with many other policies to strengthen their management of education activities more so access to education for learner living with disability(The Government of Kenya, 2013; Government of Kenya, 2003; and Republic of Kenya, 2001). The Kenya constitution articles 53, 54, 55, 56, 57, and 59 also emphasize on provision of free and compulsory basic education to all children as their basic right, and emphases on promotion of Kenyan Sign language, Braille and other communication formats and technologies accessible to persons with disabilities. Equally, gender policy designates for increase participation, retention and completion for learners with special needs and disabilities by proving enabling environment, draw a flexible curriculum, train personnel, and provision of equipment. RoK, (2010); Republic of Kenya, (2011); and Republic of Kenya, 2(013). All these activities success require government total involvement in policy implementation.

\subsection{Parental Support}

Disable children more so learner need to be supported in all activities they undertake both at home and school. The assistance can be moral, or financial given many equipment and devises they need for their educational life. Discussion with the 3 learners living with disability over support they get from their parents, 1 said minimal, while 2 indicated non. Teachers views about parents' role in all the 3 different focus group was the same answer, "parents role is not seen". Also, three principals observed the role of parents as "less active" in supporting schools activities. Both education officer stated, parents' role in school management as "big". However, parents when asked whether they participate in schools' activities, one said no, while another one said yes During the discussion with teachers, principals and education officers it came out that parents are supposed to be part of policy implementation through a known government structure referred to as PTA.

Parents action are found not to go well with principles of policy implementation suggested by Pressman J L \& Wildavsky A, (1973) that viewed implementation as a technique where set goals and actions interact for a purpose, here the aspect of action is missing set goals are 
available but implementers are nowhere. It is therefore important that proper means be discovered to bring parents on board. Many studies have tried to come up with reason for non-participant to include cultural discrimination, traditional values, deep sense of spirituality and prejudice towards them, feeling out placed in the society (Giacchino, S,. \& Kakabadse, 2003; Groce, 2004; Anthony, 2009; Polat, 2011; Ibrahim, 2013; Donohue \& Bornman, 2014; and Alothman, 2014).

\subsection{Summary of the Findings, Conclusion and Recommendation}

\subsection{Summary of the Findings}

Policies for managing access to education for disability learners are designed in such away structures are created by policy maker to support policy implementers in decision making

Most of the people who are supposed to benefit from access to education are not aware of government provisions, existences of special schools or being part of policy implementation in various schools' due lack of awareness

Societal way of thinking about disability is a big blow to policy implementers given that it affects all parties involved, parents and children feel out placed in the community and a shamed to share with others their experiences due to what culture harbours in them.

When it comes to curriculum policy content on running schools for disable learners tend to overpower reality on the ground. Curriculum in place is not friendly to all types of disable learners, moreover it is managed administratively by authoritative will of policy maker with little view on experiences.

Infrastructural facilities need to be considered as per the type of disability a learner has. It is hard for policy implementation to take place when some learners are in school but not accessing education comfortably.

Teachers are most central to policy makers in school situation, they ensure all activities policy entails are adhered to. They work under rules and regulation following prescribed output.

Looking at the stakeholder, the government tends to determine the policy context of disable learners. It gives direction to all implementers at different levels, it also provides required needs to make implementation a success. Equally, the government decides on roles of each stakeholder. Study noted being of many sponsor, however, catholic church seems to give a lot of support to disable learners.

Parent support is found to be minimal, more so in secondary schools where they are legally supposed to participate. They seem to limit their mingling with people to enhance their ability to support because of stigmatization

\subsection{Conclusion}

The purpose of this study was access to education for learners living with disability in Kenya; a study of policy implementation and strategies in Siaya, and Kisumu counties. I used a 
phenomenological approach to know individual live experiences in so far as policy implementation for learners living with disability is concern. The research made references to theories of policy implementation Top down, bottom up, and even hybrid. Gained from the works of Pressman J L \& Wildavsky A, (1973), Mazmanian, D.A. and Sabatier, (1983) Meier, O'Toole, \& Jr., (2003). Hogwood, B.W. and Gunn, (1984) Hjern Benny and Hull Christopher, (1981) Bardach, 1977 and Lipsky, 2009; Lipsky, 20108 variables were isolated after in-depth interviews, and analysis of their experiences, this follows J. Creswell, (2009) Yin, (2011); and Tashakkori, A.,\& Teddlie, (2003) studies that claims that qualitative approach isolate various stages in data analysis to include; getting used to data from the field, coming up with codes, providing themes, revising themes, name themes, finally coming up with a conclusive report. This study viewed decision making, parental support, curriculum, role of teachers, infrastructural facilities, cultural beliefs, awareness, and stakeholders support as key factors affecting policy implementation in one way or the other.

\subsection{Policy Recommendation}

Education being an important investment Kenya government is interested in offering all children regardless of their status. The findings of this study can give so many directions to policy makers to make implementation of access to education for disable learners a success

The government need to come up with a policy on strategy of decision making in special school setup. Formal structured decision making may not do very well when situations are uncertain with inadequate workforce, less facilitations and with prescribed output. Should consider applying a proportionate mix of Top down, bottom up, and even hybrid theories.

Policy makers need to consider coming up with a policy on research on disable learners specifically on befitting curriculum, facilities, and environmental infrastructural needs that can make them more comfortable to access education. The research should consider various types of disabilities and emerging issues

Government need to come up with a policy of employing at least a given number of trained teachers in special education in all schools to deal with any disable learner who might want to be admitted in a regular school set up

Government need to come up with tangible policy to curb abuses, harassment, and intimidation of disability people in the society more so children. Though Kenya constitutions and disability act highlights it, strict measure are need.

Policy makers need to consider a policy of ensuring all schools to have facilities for any type of disable learner who might wish to access education there.

Government should come up with a policy to have sign language taught in schools like any other languages, this can assist reduce stigmatization among deaf people in the society and increase deaf learners' participation in nation building.

Finally, government should come up with a policy how to support disable children from infant to primary level given that most children well-being are taken care of when they reach secondary school. 


\section{Contribution of the study}

This study stands to be unique in its own since most studies on access to education by disable children usually use theories of disability to analyses their data. This however uses policy implementation theories to come up with the findings.

The study notes from most of the literatures reviewed that none of the studies had ever looked at decision making as one of the factor that influence policy implementation for disable learners to access education. It is only this study while considering policy implementation theories noticed this gap

On curriculum front, the study noticed the need to have sign language taught in schools like any other languages, this can assist the problem of over depending on English and Kiswahili as a media of communication in teaching all subject.

\section{Acknowledgement}

I wish to give my distinct gratitude and utmost thanks to my advisor Professor Dr. Ploy Suebvises for her academic direction in the development, defence, and modification of this dissertation. Am principally grateful for support provided in the formulation and refinement of the study topic. Throughout the entire process, Ploy was a relentless source of inspiration and information which propelled me through the process Her passion for developing knowledge made her spend endless hours introducing me to and perfecting my understanding of research right from the time I developed interest in qualitative research.

I would like to thank my committee members Professor Ponlapat Buracom, Ph.D., and Professor Thanapan Laiprakobsup Ph.D. for serving as my committee, I thank them so much for reading my work in a record time despite its bulkiness. Equally I also recognize my proposal defence committee Professor Boon-anan Phinaitrup, Prof Anchana NaRanong, and Professor Ploy Suebvises for shaping my work to the required standard. Finally, I acknowledge all NIDA professors who taught me throughout the course work. Much thanks go to Orapin and GSPA staff for their assistance and kindness.

\section{References}

Alothman, A. (2014). Inclusive Education for Deaf Students in Saudi Arabia : Perceptions of Schools Principals, Teachers and Parents By Abdulaziz Alothman A thesis submitted in part fulfilment of the requirements of the University of Lincoln for the degree of Doctor of Philosophy.

Andrews, M., Squire, C., \& Tamboukou, M. (2015). Doing Narrative Research Second Edition Edited by, (May), 0-26.

Anisur, R. K., \& Shahriar, K. (2016) A Critical Insight into Policy Implementation and Implementation Performance; public policy and administration. T, 15, Nr. 4 / 2016, 15(4), 538-548 ISSN 1648-2603 (print) ISSN 2029-2872 (online)

Anthony, J. H. (2009). Towards Inclusion: Influences of Culture and Internationalization on Personhood, Educational Access, Policy and Provision for Students with Autism in Ghana. 
PhD Thesis, University of Sussex.

Babbie, E. (2007). The practice of social research. Belmont: Thompson Wardsworth.

Bardach, E. (1977). The Implementation Game. Upper Saddle River, NJ: Prentice Hall.

Beamish, W., Meadows, D., \& Davies, M. (2010). Benchmarking teacher practice in Queensland transition programs for youth with intellectual disability. The Journal of Special Education, 45 (4), 227-241. https://doi.org/10.1177/0022466910366602

Berman, P. (1978). The study of macro and micro implementation of social policy. Public Policy. https://doi.org/10.1177/009539979102200404

Bhuyan, A., Jorgensen, A., \& Sharma, S. (2010). Taking the pulse of policy: the policy implementation assessment tool. Washington, DC: USAID.

Bulat, A. M. H. J. (2017). Disabilities Inclusive Education Systems and Policies Guide for Low- and Middle-Income Countries. RTI International, 42. https://doi.org/https://doi.org/10.3768/rtipress.2017.op.0043.1707

Burke, D. E J. (2015). Access Now: Exploring the Perceptions and Experiences of College Access for Today's Youth.

Callan, L., \& Ed, E. M. (2018). A case study examining the inclusion of children with special educational needs in a mainstream primary school.

Chandarasorn, V. (2005). An Integrated Theory of Public Policy Implementation. Bangkok.: Sahai-Block Printing. In Thai.

Charles. (2015). Assessing the challenges of teaching and learning of hearing impaired students enrolled in regular primary and secondary schools in tanzania. Open university tanzania

Child, R. T. (2016). Deaf Children's Access to Quality Education in the Kilimanjaro Region. https://doi.org/www.childreachtz.org

Chomba, M. J., Mukuria, S.G., Tumuti, S., \& Bunyasi, B. A. (2014). Education for Students with Intellectual Disabilities in Kenya: Challenges and Prospects. Disability Studies Quarterly, 34(4), 1-10. https://doi.org/10.18061/dsq.v34i4.3846

Clerke, S. (2015). Investigation of post-school transition programs being provided for students with an intellectual disability in special schools in Victoria. MED Thesis, Melbourne Graduate School of Education, The University of Melbourne.

Creswell, J. W. (2009). Research design: Qualitative, quantitative, and mixed methods approaches $\left(3^{\mathrm{rd}} \mathrm{Ed}\right.$.). Thousand Oaks, CA: Sage.

Crosby, S. (2015). Barriers to access: The experience of students delaying the request for accommodations at an open-access college.

Donohue, D., \&Bornman, J. (2014). The challenges of realising inclusive education in South 
Africa. South African Journal of Education, 34(2), 1-14. https://doi.org/10.15700/201412071114

Egon, G. G. (1990). paradigm dialogue.pdf.

Elmore, R. E. (1978), Organizational Models of Social Program Implementation, Public Policy, 26(2), 185-228.

ELSEN Directorate; Department of Education. (2001). Education White Paper 6: Special needs education: Building an inclusive education and training system. Pretoria.

Elward, E (2011). Increasing Latino Access to Higher Education: A suburban District's Design and Implementation.

Foloştină, R., Duţă, N., \& Prăvălici, A. (2014). The Attitudes of Teachers Towards Integrating Students with Intellectual Disability in Regular Schools in Romania. Procedia - Social and Behavioral Sciences, 141, 506-511. https://doi.org/10.1016/j.sbspro.2014.05.088

Franke, V., \& Guidero, A. (2012). Engaging local stakeholders: A conceptual model for effective donor-community collaboration. Institute for homeland security solutions.

Frankel, E. B., Gold, S., \& Ajodhia, A., M. (2010). International Pre-School Inclusion: Bridging the Gap between Vision and Practice. Young Exceptional Children, 13(5), 2-16. https://doi.org/10.1177/1096250610379983

Fritton, S. C. (2009). The bridge to postsecondary education for students with disabilities: Perceptions of emerging best practice in preparation to access accommodations and communication across systems. ProQuest Dissertations and Theses, 372.

Geyer, A., Putz, J., \& Misra, K. (2017). International journal of educational management. International Journal of Educational Management, 31(7), 1042-1053. https://doi.org/10.1108/IJEM-10-2016-0203

Glaser, M., \& Van Pletzen, E. (2012). Inclusive education for deaf students: literacy practices and South African sign language. Southern African Linguistics and Applied Language Studies. 30(1), 25-37. https://doi.org/10.2989/16073614.2012.693707

Glick, P. (2008). What policies will reduce gender schooling gaps in developing countries: Evidence and interpretation World Development, 36(9), 1623 - 1646. https://doi.org/10.1016/j.worlddev.2007.09.014

Goggin, M. L., Bowman, A., Lester, J., \& O’Toole, L. (1990). Implementation theory and practice: Toward a third generation. New York: Harper Collins.

Gok. (2010). Laws of kenya. Kenya Law Reports, (February), 191.

Halfon, S., \& Friendly, M. (2013). Inclusion of young children with disabilities in regulated child care in Canada. A snapshot: Research, policy and practice. Occasionnal Paper $\mathrm{N}^{\circ} 27$ Childcare Ressource and Resarch Unit. Toronto.

Harrison, N. O. (2013) Access, Retention, and Progression of Marginalized Students in Kisii 
Schools, Kenya.

Hill, M., \& Hupe, P. (2002). Implementing Public Policy. Athenaeum Studi Periodici Di Letteratura E Storia Dell Antichita. https://doi.org/10.1201/9781420017007.fmatt

Hjern, B. (1982). Implementation research: The link gone missing. Journal of Public Policy 2(3), September: 301-308. https://doi.org/10.1017/S0143814X00001975

Hogwood, B. W., \& Gunn, L. (1984) Policy Analysis for the Real World. Oxford: Oxford University Press.

Howlett, M., \& Michael, R. (1995). Studying Public Policy: Policy Cycles and Policy Subsystems. Don Mills, Ont.: Oxford University Press Canada

Ibrahim, M. (2013). Status of Inclusive Education of Hearing Impaired Students in Primary Schools: The case of Yekatit 23 Special Primary School and Mekanissa School for the Deaf in Addis Ababa. MA Thesis, Institute of Educational Research, Addis Ababa University, Ethiopia.

Karen, A. C. (1991) Access to higher education: A study of state-level changes in access from 1969 to 1979 to 1989.

Karr, V. L. E., Ashley, van S., \& Jacob, B. C. (2017). No One Left Behind: A review of social protection and disability at the World Bank. Disability and the Global South, 4(1), $1112-1142$.

Kavouni, K. (2016). Primary School Teachers' Perceptions on Inclusive Education for Students with Mental Disabilities: A Comparative Case Study between Greece and Sweden. Master's Degree Studies in International and Comparative Education, Stockholm University, Sweden.

Kelly, K. (2006). Lived experience and interpretation: The balancing act in qualitative analysis. In M. Terre Blanche, K. Durrheim, \& D. Painter (Eds.), Research in practice: Applied methods for the social sciences ( $2^{\text {nd }} \mathrm{Ed}$., pp. 354-356). Cape Town: University of Cape Town Press.

Kett, M. (2012). Skills development for youth living with disabilities in four developing countries. Background paper prepared for the Education for All Global Monitoring Report 2012.

KNHRC. (2014). From Norm to Practice, A status report on implementation of the rights of persons with disabilities in Kenya. Nairobi

KNHRC. (2016). Convention on the Rights of Persons with Disabilities. Nairobi - Kenya.

Kochung, E. (2003). Report on the task force on special needs education appraisal exercise. Nairobi, Kenya: Ministry of Education Science and Technology.

Lasswell, H. D. (1970) The emerging conception of the policy sciences, Policy Sciences, 1(1), 3-14. https://doi.org/10.1007/BF00145189 
Lester, J. P., Bowman, A. O., Goggin, M. L., \& O’Toole, L. J. (1987). Public policy implementation: Evolution of the field and agenda for future research. Policy studies review. 7, 200-216. https://doi.org/10.1111/j.1541-1338.1987.tb00038.x

Lewin, K. (2008). Why some education for all and millennium development goals will not be met: Difficulties with goals and targets, in: Chisholm, L., Bloch, G., \& Fleisch, B. Education, growth, aid and development: Towards education for all (Hong Kong: Comparative Education Research Centre).

Lipsky, M. (1980). The Critical Role of Street-Level Bureaucrats. In Street-Level Bureaucracy: Dilemmas of the Individual Public Services.

Lipsky, M. 2010. Street-level bureaucracy. New York: Russell Sage Foundation

Louise, C. (2013). A case study examining the inclusion of children with special educational needs in a mainstream primary school [M.Ed. dissertation]. Dublin: Trinity College Dublin.

Lucianna, J. B. (2015). Faculty knowledge and attitudes regarding students with disabilities in higher education.

Marcella, D., \& Carlo, T. M. K. (2014). Including Children with Disabilities in Primary School: The Case of Mashonaland, Zimbabwe: Leonard Cheshire Disability and Inclusive Development Centre.

Marshall, C., \& Rossman, G. B. (2011). Designing Qualitative Research (5th ed.). California: Sage Publications.

Matland, R. E. (1995), Synthesizing the Implementation Literature: The Ambiguity Conflict Model of Policy Implementation, Journal of Public Administration Research and Theory: J-PART, 5(2) (Apr. 1995) 145-174.

Mazmanian, D. A., \& Sabatier, P. A. (1983), Implementation and Public Policy. Glenview, III.: Scott, Foresman

Mazmanian, D. A., \& Sabatier, P. A. (1989). Implementation and public policy.Lanham:University Press ofAmerica.

McCool, D. C. (1995). The theoretical foundations of policy studies. In D. C. McCool (Edt.) Public policy theories, models and concepts: An anthology (pp.1-27). Englewood Cliffs, NJ: Prentice-Hall.

Meier, K. J., \& O’Toole, L. J. (2003). Public Management and Educational Performance: The Impact of Managerial Networking. Public Administration Review, 63(6), 689-699. http://doi.org/10.1111/1540-6210.00332.1

Moloi, K. C., \& Motaung, R. R. (2014). Admission of and Service Provision for Deaf Students at a University of Technology. Mediterranean Journal of Social Sciences, 5(10), 370-375. https://doi.org/10.5901/mjss.2014.v5n10p370

Moyi, P. (2012). Access to education for children with disabilities in Uganda: Implications for 
Education for All. Journal of International Education and Leadership, 2(2), 1-6.

Mtuli, T. C. (2015). Assessing the challenges of teaching and learning of hearing impaired students enrolled in regular primary and secondary schools in Tanzania. Open University Tanzania.

Muchiri, N., \& Roberson, L. (2000). Including the excluded: An inclusive education project in Congress, North Kenya. Paper presented at the beginning of the International special Education University of Manchester.

Muiti, M. (2010). Hindrances to Effective Learning of Pupils with Hearing Impairment in Meru North District-Kenya. International Journal of Business Performance Management, 2(3), 15-20.

Munene, I. I., \& Ruto, S. J. (2010). The right to education for children in child labour: Empirical evidence from Kenya. International Review of Education, 56(1), 127-147. https://doi.org/10.1007/s11159-010-9152-1

Musengi, M., \& Chireshe, R. (2012). Inclusion of Deaf Students in Mainstream Rural Primary Schools in Zimbabwe: Challenges and Opportunities. Stud Tribes Tribals, 10(2) 107-116. https://doi.org/10.1080/0972639X.2012.11886648

Musengi, M., Ndofirepi, A., \& Shumba, A. (2012). Rethinking Education of Deaf Children in Zimbabwe: Challenges and Opportunities for Teacher Education. Journal of Deaf Studies and Deaf Education, 18(1), 62-74. https://doi.org/10.1093/deafed/ens037

Muthili, C. S. (2010). Factors Influencing Inclusion of Learners with Special Needs in Regular Primary Schools in Rachuonyo District, Kenya. MED Thesis (SNE), Kenyatta University, Kenya.

Muthukrishna, N., \& Schoeman, M. (2000). From "Special Needs" to "Quality Education for All": a participatory, problem-centred approach to policy development in South Africa. International Journal of Inclusive Education, 4(4), 315-335. https://doi.org/https://doi.org/10.1080/13603110050168023

Mwangi, E. M., \& Orodho, J. A. (2014). Challenges Facing Implementation of Inclusive Education in Public Primary Schools in Nyeri Town, Nyeri County, Kenya. Journal of Education and Practice, 5(16), 118-125.

Najjingo, H. (2009). Challenges of Accessing All-Inclusive Education Services by Children with Disabilities (Cwds): A Case of Mijwala Sub-County Ssembabule District. MA Dissertation, Makerere University.

Nathan J. C, (2011). Life after disability diagnosis: The Impact of Special Education Labelling in Higher Education.

Nyambedha, E. O., Wandibba, S., \& Aagaard-Hansen, J. (2001). Policy implications of the inadequate support systems for orphans in Western Kenya. Health Policy, 58(1), 89-96. https://doi.org/10.1016/S0168-8510(01)00145-2 


\section{Macrothink}

Journal of Public Administration and Governance ISSN 2161-7104 2018, Vol. 8, No. 2

Palumbo, D. J., \& Calista, D. J. (1990). Implementation and the policy process. New York: Greenwood Press.

Patton, M. Q. (2002). Qualitative research \& evaluation methods $\left(3^{\mathrm{rd}} \mathrm{Ed}\right.$.). Thousand Oaks, CA: Sage.

Patton, Q., \& Cochran, M. (2010). A Guide to Using Qualitative Research Methodology. Qulitative Research, 1 .

Polat, F. (2011). Inclusion in education: A step towards social justice. International Journal of Educational Development, 31(1), 50-58. https://doi.org/10.1016/j.ijedudev.2010.06.009

Pressman, J. L., \& Wildavsky, A. (1973). Implementation: How Great Expectations in Washington Are Dashed in Oakland.

Pulz, H., \& Treib, O. (2007). Implementing public policy. In Fischer, F., Miller, G.J. and Sidney, M.S..Handbook of public policy analysis: Theory, politics and methods. New York: C R C Press

Republic of Kenya (1999). Totally Integrated Quality Education and Training (TIQET) Report of the Commission of Inquiry into the Education System of Kenya. Nairobi: Government Printers.

Republic of Kenya (2001). Children's Act (2001). Nairobi Government Printers.

Republic of Kenya (2003). Persons with Disabilities Act, 2003. Nairobi: Government Printer.

Republic of Kenya (2010). The Constitution of Kenya, 2010. Nairobi: Government Printers.

Republic of Kenya. (1964). The Committee on Care and Rehabilitation of the Disabled; The Ngala Mwendwa Report. Nairobi - Kenya Government Printer

Republic of Kenya. (2007). Kenya Vision 2030:A Globally Competitive and Prosperous Kenya.

Republic of Kenya. Children and Social Development Gender Policy (2011). Kenya.

Republic of Kenya. Laws of Kenya; Basic Education Act (2013). Kenya.

Republic of Uganda. Constitution of the republic of Uganda (Article, 29) (1995). Uganda:www.track.unodc.org/LegalLibrary/.../Uganda/.../Uganda\%20Constitution\%20(1995 ).https://doi.org/www.track.unodc.org/LegalLibrary/.../Uganda/.../Uganda\%20Constitution\%2 0(1995)

RoK. (1964). Education Commission, Ominde Report. Nairobi - Kenya.

RoK. (1976). Report of the National Committee on Education Objectives and Policies. Nairobi - Kenya.

RoK. (1993). Special Education Review on Disability.

RoK. (2010). Constitution of Kenya. Nairobi - Kenya. 
Rubin, A., \& Babbie, E. R. (2015). Research Methods for Social Work.

Shabaya, J. \& Konadu-Agyemang, K. (2004). Unequal access, unequal participation: Some spatial and socio-economic dimensions of the gender gap in education in Africa with special reference to Ghana, Zimbabwe, and Kenya. Compare, 34(4), 395-424. https://doi.org/10.1080/0305792042000294805

Sifuna, D. N. (2007). The challenge of increasing access and improving quality: An analysis of universal primary education interventions in Kenya and Tanzania since the 1970s. International Review of Education, 587-699. https://doi.org/10.1007/s11159-007-9062-z

Somerset, A. (2011). Access, cost, and quality: tensions in the development of primary education in Kenya. Journal of Educational Policy, 26(4), 483 - 497. https://doi.org/10.1080/02680939.2011.554998

Stewart, J. J., Hedge, D. M., \& Lester, J. P. (2008). Public policy: An evolutionary approach. Boston: Thomson Wordsworth

Tashakkori, A., \& Teddlie, C. (2003). Handbook of mixed methods in social and behavioral research. Thousand Oaks, California: Sage.

Tefera, B., Admas, F., \& Mulatie, M. (2016). Education of Children with Special Needs in Ethiopia: Analysis of the Rhetoric of „, Education For All "e and the Reality on the Ground The Ethiopian government has registered a prodigious stride in improving educational access in the last couple of decade, $X X X V(1), 45-97$.

Terre, B. M., \& Kelly, K. (1999). In M. Terre Blanche \& K. Durrheim (Eds.), Research in practice: Applied methods for the social sciences. Cape Town: University of Cape Town Press.

The United Republic of Tanzania. (1995). Education for All (EFA) report for Tanzania mainland.

Thomas, R. D. (1976). Policy Analysis What Governments do, Why they do it, and What difference it makes (Second). Alabama USA: The University of Alabama Press.

Tichaona Mapolisa, T. T. (2013). Instructional Supervisory Practices of Zimbabwean School Heads. Greener Journal of Educational Reseach, 3(7), 354-362. https://doi.org/10.15580/GJER.2013.7.070313700

UKaid, D. (2015). Guidance Note: A DFID practice paper. Education for Children with Disabilities - Improving Access and Quality, 1-22.

UN. (2015). Transforming our world: the 2030 Agenda for Sustainable Deve lopment., (Available at: http://www.refworld.org/docid/57b6e3e44.html).

UNESCO (1990) World Declaration on Education for All and Framework for Action to Meet Basic Learning Needs. International Consultative Forum on Education for All. Paris: UNESCO 
UNESCO (2010). Reaching the marginalized. EFA Global Monitoring Report 2010. Oxford: Oxford University Press.

UNESCO (2014), report on education progress in access to education

UNESCO (2015). The Right to Education for Persons with Disabilities: Overview of the Measures Supporting the Right to Education for Persons with Disabilities reported on by Member States. Paris: UNESCO.

UNESCO, (1989). Promoting the Right of Right of Children with Disabilities.

UNESCO, (2017). Education for Sustainable Development Unit (ESD).

UNESCO. (2001). Education Policies and Strategies, The Right to Education: Analysis of UNESCO's Standard setting Instruments. Paris

UNESCO. (2003). Disability, Poverty, and Education. New York.

UNESCO. (2009). Policy Guidelines on Inclusion in Education. Paris.

USC. Republic of Zimbabwe. (2001). Education Act of Zimbabwe. Harare.

Van Meter, D. S., \& Van Horn, C. E. (1975). The Policy Implementation Process: A Conceptual Framework. Administration \& Society. https://doi.org/10.1177/009539977500600404

Villenas, C. (2014) Explaining the Disability gap in Access to Postsecondary Education: The Role of Social Factors.

Wacker, J. G. (1998). A definition of theory: Research guidelines for different theory building research methods in operations management, Journal of Operations Management, 16, 361-385. https://doi.org/10.1016/S0272-6963(98)00019-9

Wanjiku, J. G. (2012). Access to University Education for Persons with Disabilities: Towards Inclusion. Master of Law Thesis, University of Nairobi.

Watson, S. F. (2009). Access To Mainstream Primary Education Environments : the Case for Pupils With an Intellectual and / or a Pervasive Developmental Disability October 2009 Department Head : Professor Mark Boyle Supervisor : Professor Rob Kitchin, (October).

WB. (2015). Social Protection and Labor Overview: Disability Overview

WHO. (2011). World Report on Disability: Disability and Rehabilitation

Winter, S. C. (1990), Integrating Implementation Research, eds. Palumbo, Dennis J, \& Calista, Donald J, 1990, Implementation and the Policy Process, Opening the Black Box, Greenwood Press

Winter, S. C. (2003), "Implementation", (Section 5) In Handbook of Public Administration, (ed.) BG Peter and J Pierre. London, Thousand Oaks, CA and New Delhi: Sage 206-211 pp.

World Bank. (2005). A Note on Disability Issues in the Middle East and North Africa. Human 
Development Department Middle East and North Africa Region.

World Health Organization and World Bank (2011). World Report on Disability, Geneva: World Health Organization, http://www.who.int/disabilities/world_report/2011/report.pdf

World Health Organization, [WHO], (1976).

Yin, K, R. (2011). Qualitative research from start to finish. New York: The Guilford Press.

Younis, T., \& Davidson. (eds) (1990). Implementation in public Policy, Dartmouth Publishing Company Ltd.

Zvoleyko, E. V., Kalashnikova, S. A., \& Klimenko, T. K. (2016). Socialization of students with disabilities in an inclusive educational environment. International Journal of Environmental \& Science Education, 11(14), 6469-6481.

\section{Copyright Disclaimer}

Copyright for this article is retained by the author(s), with first publication rights granted to the journal.

This is an open-access article distributed under the terms and conditions of the Creative Commons Attribution license (http://creativecommons.org/licenses/by/4.0/). 